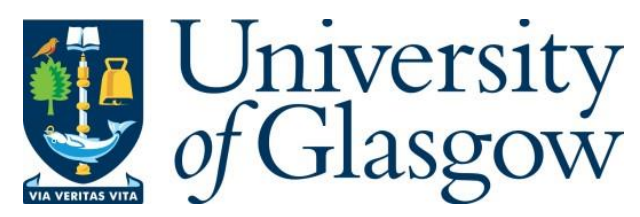

Reinsberg, B. (2017) Organizational reform and the rise of trust funds: lessons from the World Bank. Review of International Organizations, 12(2), pp. 199-226.

There may be differences between this version and the published version. You are advised to consult the publisher's version if you wish to cite from it.

http://eprints.gla.ac.uk/172862/

Deposited on: 5 November 2018

Enlighten - Research publications by members of the University of Glasgow

http://eprints.gla.ac.uk 


\title{
Organizational reform and the rise of trust funds: Lessons from the World Bank
}

\author{
Bernhard Reinsberg \\ January 10, 2017
}

\begin{abstract}
Over the past two decades, earmarked funding to international development organizations through special-purpose trust funds has increased greatly. This paper studies the incentives for trust funds from the perspective of multilateral agencies, notably the World Bank. A theoretically intriguing type of funds are so-called "pass-on funds," in which one unit hosts the fund, then passes on its resources to another type of unit for implementation. Each unit has different preferences for the specific types of activities to be supported by the fund. Interviews with World Bank staff and complementary documents demonstrate the rationale for pass-on funds and the associated division of labor between fundraising network units and implementing regional units. While pass-on funds reflect an efficient division of labor between functionally specialized units, they increase the misalignment between sector-specific global priorities and country-specific needs. Organizational reform drove the sudden explosion of pass-on funds around the millennium turn, facilitated by growing availability of donor monies for specific sectors and by lenient internal regulation. Organizational reform undermined budget autonomy of sector units, causing those units to seek new funds in their areas of expertise. A number of reform features also reduced administrative budgets of country units, increasing their demand for pass-on funding grants. The results contribute to the emerging literature on earmarked funding and highlight the need to consider international organizations as heterogeneous actors.
\end{abstract}

Keywords: Trust funds; multilateral agencies; bureaucratic politics; collective agents JEL codes: D73, F13, O19

I thank Kurt Annen, Katharina Hofer, Stephen Knack, Daniel Nielson, Marie Riekhof, participants of the Political Economy of International Organizations Conference in Salt Lake City, January 7-9, 2016, and the Young Swiss Economists Meeting in Zurich, February 11-12, 2016, the 


\section{Introduction}

Trust funds, channeling grant resources to international development organizations for specific development purposes, have become an important tool in the global aid architecture. Trust funds are popular with donors because of their tremendous flexibility, compared to traditional sources of multilateral finance (e.g., OECD 2011; Reinsberg, Michaelowa, and Knack 2016; Eichenauer and Reinsberg 2017).

While trust funds have proliferated in the last twenty years, their governance arrangements also have become increasingly complex. An exemplary case of such complexity is represented by the so-called "pass-on funds" at the World Bank. Unlike trust funds that individual units raise to support their own work program, pass-on funds entail a division of labor within the multilateral bureaucracy, with a global sector unit raising the funds, managing the overall program, and relating to donors relations, while a country unit implements the programs financed by these funds. This feature raises important theoretical questions. How do pass-on funds emerge? What makes this institutional arrangement beneficial to the relevant units? Which conditions sustain the implied division of labor? A related question pertains to timing. Why did pass-on funds take off suddenly around the millennium turn?

This paper answers these questions by studying the related historical developments at the World Bank. While focused on the World Bank, the present analysis may be generalized to all international development organizations. All major international development organizations consist of headquarters and field offices, with headquarters often developing sector-specific programs and field offices implementing these program-supported activities at the country level. At the World Bank, "Sector Managing Units" (SMUs) prepare specific projects, while "Country Managing Units" (CMUs) interact with recipient countries and manage project portfolios in multiple sectors. This division of labor delivers quality projects relevant to specific country needs, but functional specialization also perpetuates differences among different units. Country units emphasize specific country needs while sector units also promote their sectors irrespective of geographical boundaries.

In addition to describing recent trust fund history and development of pass-on funds, this paper explores goal conflicts and bargaining processes in functionally differentiated organizations (e.g., Barnett and Finnemore 2004; Weaver 2008; Gra-

editors of this issue, and two anonymous reviewers for helpful comments on this paper. I benefited greatly from fruitful exchange with Patrick Bayer, Sebastian Fehrler, Tobias Lechtenfeld, Skip Lupia, Daniel Magleby, Carlo Prato, and Maik Schneider. 
ham 2013), links between organizational structure and organizational performance (e.g., Barnett and Finnemore 1999; Caughey, Cohon, and Chatfield 2009; Bauer and Ege 2016), and determinants of trust funds. Previous studies on the determinants of trust funds emphasize the donor perspective, some arguing that trust funds allow donors to regain control over unfaithful agents (Sridhar and Woods 2013), others focusing on divisions among donors to explain why trust funds have proliferated (Graham 2015; Bayram and Graham 2016; Reinsberg, Michaelowa, and Knack 2016). Motivations for multilateral agencies to establish trust funds have not been systematically analyzed, though they have been discussed cursorily (e.g., Michaelowa and Michaelowa 2011; Mahn 2012; Reinsberg, Michaelowa and Eichenauer 2015).

A focus on pass-on funds facilitates more thorough analysis of agency motivations and generates new explanations for trust funds beyond the obvious explanation that agencies use the funds to grow their budgets. Organizational reforms can play a key role by generating powerful incentives to create new funds. For example, the "Strategic Compact" reforms initiated by the World Bank in 1997 undermined budget autonomy of sector units, which encouraged these units to use pass-on funds to regain autonomy. While the rapid growth of pass-on funds may help the World Bank increase its position against multilateral competitors, it most likely undermined ongoing efforts to increase the relevance of development projects for specific country priorities. Because pass-on funds represent sector interests at the global level, they inherently ignore specific country interests (IEG 2011).

My analysis draws primarily on qualitative evidence from semi-structured interviews conducted at the World Bank headquarters in 2013, augmented by trust fund program documents, annual budget reports, and evaluation studies from the World Bank. My choice of method recognizes that the creation of pass-on funds as a specific form of financing is a singular event, but once established, pass-on funds involve repeated interactions between host units and implementing units that can be studied quantitatively. There is an apparent link between the reasons for establishment of pass-on funds and patterns governing their use. Web Appendix A provides additional evidence consistent with the findings presented here.

I proceed as follows. Section 2 discusses historical developments of trust funds at the World Bank, introduces the phenomenon of pass-on funds, and specifies research questions. Section 3 reviews theoretical literature on trust funds, identifies current gaps, and demonstrates how analyzing pass-on funds enhances our understanding of international organizations. Section 4 explores potential explanations for the rise of pass-on funds. Section 5 presents original empirical analysis drawing on the case 
of the World Bank. Section 6 discusses the consequences of pass-on funds for the functioning of the World Bank and probes the potential for generalization beyond the World Bank context. It also reassesses some prevailing arguments in the relevant theoretical literature. Section 7 concludes.

\section{The rise of pass-on funds at the World Bank}

Pass-on funds are a special type of trust fund involving a particular division of labor between at least two units of an international development organization. One unit hosts the fund, maintaining donor relations and allocating program funds to specific projects, and at least one other unit implements specific projects supported by the fund.

Pass-on funds are common in larger multilateral agencies such as the United Nations which comprise a bundle of functionally specialized entities. Under the pooled funding mechanism, administered by the Multi-Partner Trust Fund Office, the United Nations Development Program allocates pass-on fund resources to multiple entities that implement resources according to their own operating procedures. ${ }^{1}$ The World Bank often uses the term "global funds" to characterize pass-on funds, because their sector programs often have global scope. However, "pass-on fund" is a more appropriate term as it emphasizes the institutional arrangement among distinct organizational units. ${ }^{2}$ This institutional arrangement involves the so-called "network anchors" as hosts and the regional units as implementers. The reverse arrangement in host-user relations is rare. As shown in Figure 1, regional units primarily use trust funds received from other units, but also raise their own funds that cannot benefit other units. Conversely, network units mostly host funds intended for implementation in another unit, while also raising funds to support their own work program. ${ }^{3}$ These patterns indicate a division of labor by which network units host trust funds and pass them on to regional units, which motivates the pass-on funds terminology. The patterns also reflect the country-based assistance model of the World Bank.

\footnotetext{
${ }^{1}$ See http://mptf.undp.org/overview/funds (accessed August 15, 2016)

${ }^{2}$ Despite some overlap, the terms are not interchangeable. All current global funds are pass-on funds, but not all pass-on funds are global (but sometimes regional). Moreover, my definition of pass-on funds also excludes financial intermediary funds because the pass-on logic does not apply to the Bank but across international organizations.

${ }^{3}$ For a disaggregated presentation of host-user relations at the level of individual units, see Web Appendix B3.
} 
Figure 1: Host-user relations in World Bank trust funds

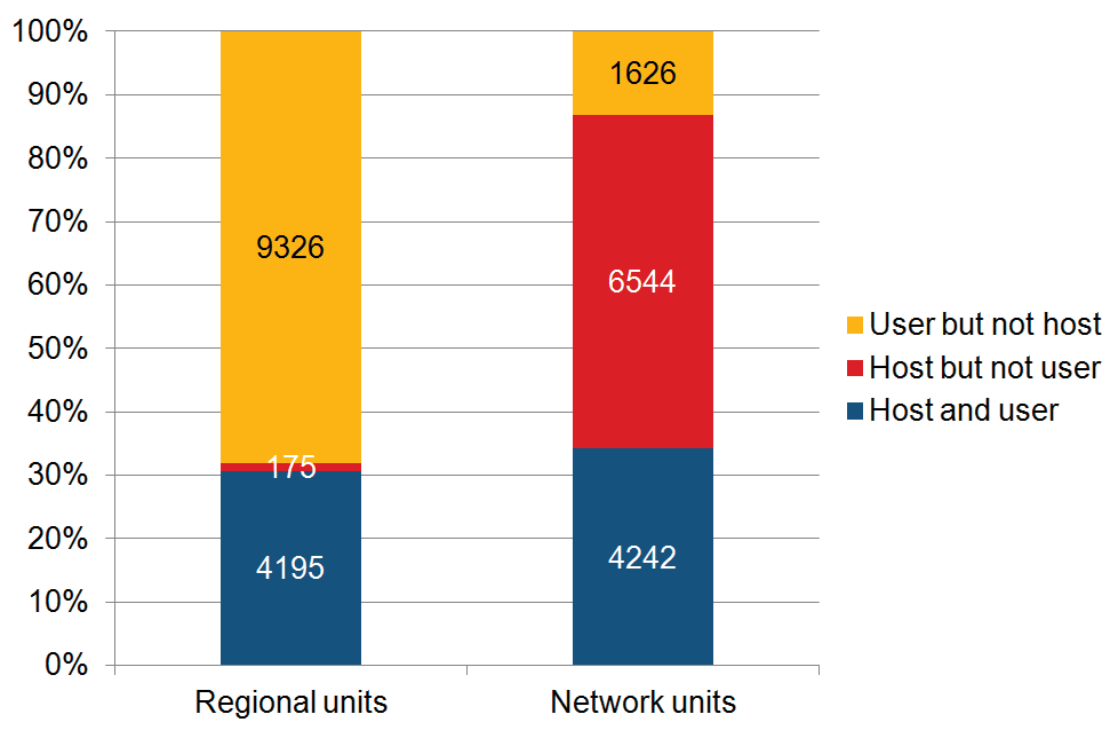

Notes: Figure shows the relative distribution of trust fund grants during FY 2002-13 aggregated over all regional units and all network units. Bar labels indicate total numbers of trust-funded grants.

Source: World Bank (2013g)

At the World Bank, the growth of has increased rapidly. In 1999, there were virtually zero pass-on funds, by 2005 there were 40, and by 2010 the number peaked at 110 (Figure 2). Furthermore, their significance in the overall trust fund business is significant. Over fiscal years (FY) 2002-13 — the longest time span for which data are available - $37 \%$ of all donor contributions went to global funds, which rely on pass-on funding mechanisms. ${ }^{4}$ An individual pass-on fund may support multiple activities, thus there are many more pass-on fund supported activities than there are pass-on funds. For example, in FY 2010, the Bank had 110 active pass-on funds, but all active pass-on funds together disbursed 2,071 individual grants (World Bank 2013h).

Pass-on funds funds are also significant in terms of grant volumes. The total size of pass-on funds in FY 2004 was USD 750 million, which doubled to USD 1.5 billion in FY 2011. This figure is almost half the expenditure from IBRD/IDA trust funds over this period. The USD 1.5 billion of pass-on funds in FY 2011 was roughly 15\% of the total grant amount committed by the World Bank to its client countries that

\footnotetext{
4 Note that Figure 2 only refers to IBRD/IDA trust funds, trust funds administered by the World Bank that benefit its own programs. For introductions to World Bank trust funds, see World Bank (2013a-b).
} 
Figure 2: The evolution of pass-on funds at the World Bank

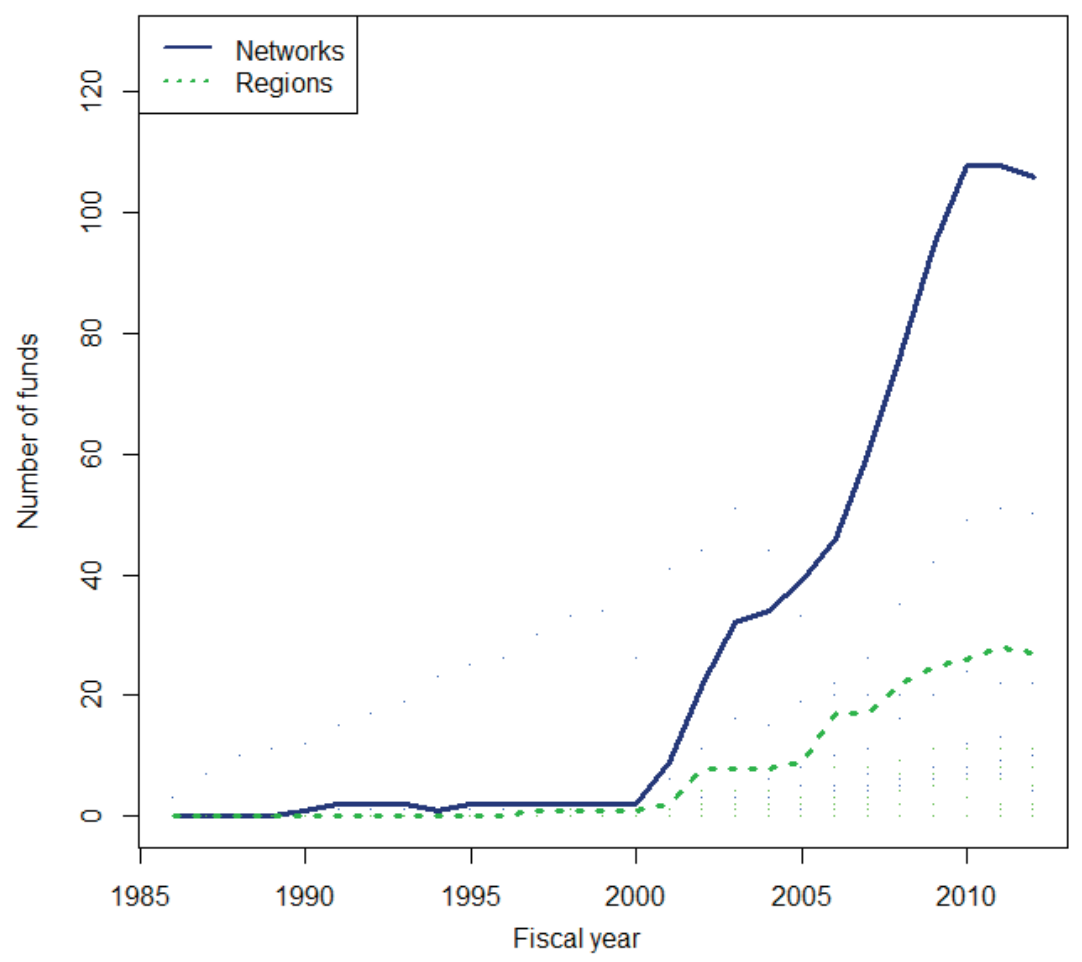

Notes: Thick lines show the total number of active pass-on funds minus terminated funds in a fiscal year by unit type. Individual dots of corresponding color show unit-specific data. The figure excludes trust funds involving the International Finance Corporation (IFC).

Source: World Bank (2013h)

year (as the grant volume equaled USD 10 billion in FY 2011).

The rapid expansion of pass-on funds contrasts with the more gradual development of other types of funds at the World Bank. While pass-on funds are a novel phenomenon, trust funds in general are not. In fact, the World Bank and other multilateral organizations have long-standing experience with trust funds to support specific development initiatives. The World Bank established its first trust fund in 1960, when several donors sought to co-finance the Indus Basin Project in Pakistan. ${ }^{5}$ Since 1960, trust funds grew slowly and were primarily vehicles for the Bank to participate in partnership programs, for example the Consultative Group on International Agricultural Research (CGIAR) in the 1970s. In the mid-1980s, the World Bank started establishing a number of consultant trust funds with bilateral

\footnotetext{
${ }^{5}$ Technically speaking, the International Development Association (IDA), also created in 1960, was the first trust fund. However, because of its broad mandate and its nearly universal membership, IDA is not considered a trust fund in the common sense of funding earmarked for special purposes.
} 
donors (World Bank 2005a: 1). In the mid-1990s, the World Bank created trust funds to address emerging development issues, for example post-conflict reconstruction, good governance, and environmental protection (Barakat, Rzeszut, and Martin 2012: 13).

In many of these trust funds, individual sector or regional units raised their own resources to support their operational work. They are called "own funds" in this paper. This is a broad term for a range of funds with different purposes. Own funds have steadily grown for decades and continue to be a significant element of grant funding at the World Bank and other multilateral organizations. Own funds allow individual units to expand their work program and hence will be established as the opportunity arises. A given unit has much flexibility in the design of own funds, which implies that they remain close to actual needs while having a lenient institutional structure (Reinsberg 2016).

In contrast, the benefits from pass-on funds may not be reaped without certain costs. Focusing on trust funds that support country operations, program effectiveness hinges on the type of funding source, notably, whether the country unit raises its own fund or whether it is supported by a pass-on fund. An independent evaluation reports that "[s]ingle-country trust funds are generally adapted to country situations and work well; this is less true for global funds that support multiple countries many of which poorly integrate and coordinate their support at the country level" (IEG 2011: 25). From the perspective of World Bank management, pass-on funds are double-edged swords: They help the organization stay relevant on global issues despite its country-focused assistance model (IEG 2011: 9), but the funds may also undermine efforts in other priority areas such as increasing the relevance of World Bank operations for recipient countries. It may not be a coincidence that long after the World Bank decentralized its operations to field offices, the alignment of operations with country needs remains remarkably poor (IEG 2011: viii). Pass-on funds warrant closer examination partly because they can alter how multilateral agencies work. The significant size and sudden growth of these funds in the World Bank require explanation and provide the empirical basis of this paper.

In addition, pass-on funds raise interesting theoretical questions. Why do passon funds exist at all? Which factors explain the sudden explosion of pass-on funds at the millennium turn? The first question touches on the rationale for pass-on funds. While this question can be studied from a donor perspective, I employ an intraagency perspective in order to better understand the incentives for the individual units involved. It appears to be puzzling that implementing units rely on pass-on 
funds rather than raising own funds to support their activities, given that units could better target the funds to their specific needs if the funds were housed in their own unit. Moreover, it is unknown what motivates host units to raise trust funds that they do not use to implement programs themselves. The case of pass-on funds hence seems to reflect an interesting case of functional differentiation at multilateral organizations and increased intra-organizational bargaining.

The second question concerns the timing of pass-on funds. Which factors came together at the millennium turn that explain the sudden takeoff of pass-on funds? It is clear that the usefulness of the funds alone does not explain the timing of their sudden growth; however, the factors underlying this new trend are yet unexplored. The goals of this paper are to establish the general case for pass-on funds, to trace the origins of pass-on funds, and to explore resulting bigger lessons for international organizations theory.

\section{Theoretical perspectives}

While my paper relates directly to the emerging literature on trust funds, I elaborate more broadly on debates in international relations, organizational theory, and the public choice of international bureaucracies for which the study of pass-on funds may bring about new insights.

Trust funds are a new mechanism of multilateral development finance. From an empirical perspective, the new multi-bi aid dataset provides opportunities to study trends in earmarked aid for a prolonged time period (Eichenauer and Reinsberg 2017). From a theoretical perspective, the rise of trust funds can be studied within a principal-agent framework. The principals are the member states, acting collectively through the governing board or individually as donors, while the agent represents the multilateral bureaucracy (e.g., Nielson and Tierney 2003; Hawkins, Lake, Nielson, and Tierney 2006; Johnson and Urpelainen 2014).

Trust fund research using the principal-agent framework is primarily from the donor perspective (e.g., Sridhar and Woods 2013; Eichenauer and Hug 2015; Graham 2015). For example, Sridhar and Woods (2013) coin the term "Trojan multilateralism" to refer to the risk of global funds undermining universal multilateralism, and conclude these funds exist because of the problem of agency slack. By earmarking their financial contributions, donors reduce the policy discretion of their agent and hence increase donors' collective control. For example, donors influenced the World Health Organization by using the Global Fund to Fight Aids, Tuberculosis 
and Malaria. Others consider goal conflicts among the principals themselves to be the main driver for earmarked funding. Graham (2016) argues that earmarked contributions are the joint product of divergent preferences regarding policies and financial costs of multilateral activities. Moreover, Eichenauer and Hug (2015) study the choice of funding channel when special-purpose trust funds become available, taking into account the role of voting rules at multilateral organizations. Finally, Reinsberg, Michaelowa, and Knack (2016) study donor participation decisions in World Bank trust funds and present evidence to suggest that individual donors trade off gains from burden-sharing in funds with more donors against gains in control in funds with fewer donors. The present paper provides a complementary perspective to these studies by exploring potential explanations for trust funds that explicitly focus on the multilateral agency perspective. This change of perspective provides some new insights, for example that trust funds rarely result from unfaithful agents and more often result from unfaithful principals.

A key debate in studies of international organization relates to the sources of autonomy of multilateral agencies. Recent literature makes significant steps to measure autonomy more precisely (e.g., Brown 2010; Conceição-Heldt 2013; Bauer and Ege 2016). For an agent to be autonomous with respect to the principal(s), it needs to have autonomous preferences as well as autonomous resources (e.g. Barnett and Finnemore 2004; Cortell and Peterson 2006; Caughey, Cohon, and Chatfield 2009; Bauer and Ege 2016). It is an open debate whether or not trust funds increase the autonomy of multilateral agents. From a donor perspective, earmarked funding constrains the agent, especially when the same donors that provide earmarked funding simultaneously reduce their core funding (e.g., UN 2012; Sridhar and Woods 2013; Browne and Weiss 2014). From an agency perspective, however, earmarked funding multiplies the available choices, especially when agencies manage to broaden the donor base. In that way, agencies can exploit differences among the donors for their own benefit (e.g., Bryner 1987; Wilson 1989; Lyne, Nielson and Tierney 2006). Unless donors establish controls costly to them - contract precision, appointment procedures, monitoring agents, "shadow bureaucracies" (e.g., Nielson and Tierney 2003; Dijkstra 2015; Parizek 2016) — agent autonomy grows with the resources under control. Therefore, it is widely assumed that bureaucracies attempt to maximize their budgets and grow their staff (e.g., Frey 1984; Vaubel 1986; Vaubel, Dreher, and Soylu 2007). Some researchers argue that agents want independence from their principals wherever possible (e.g., Reinalda and Verbeek 2004; Hawkins and Jacoby 2006; Johnson 2014). 
In this debate, autonomy refers to autonomy of a single agent versus its principals. This ignores that such autonomy may not be the same for every unit inside a multilateral bureaucracy. In general, different units within the same organization may have different preferences (Barnett and Finnemore 1999: 724). Different units might also have different access to external resources. For both reasons, considering agencies as heterogeneous actors may be necessary in some contexts for the concept of agent autonomy to be sensible.

In addition, the struggle for autonomy may not be limited to the principal-agent relationship. In fact, this struggle also occurs within a collective agent. While it had long been argued in the domestic context that bureaucrats strive for power, prestige, security, and loyalty (Downs 1967; Fiorina and Noll 1979; Breton and Wintrobe 1982), the power struggles within international bureaucracies tend to be neglected. As an exception, Graham (2013) provides case evidence from the World Health Organization that headquarters in Geneva were unable to control local field offices, causing country programs in health systems to be poorly connected to the donors' goals embraced at headquarters. No study of trust funds exists to date that uses these insights, leaving important gaps in our understanding of trust funds. Current explanations do not adequately account for the emergence of certain types of trust funds. In this paper, I provide an explanation for the rise of pass-on funds by studying their implications on the intra-organizational patterns of authority.

Recent literature particularly from organizational theory emphasizes the role of organizational structure (e.g., Gehring 2009; Trondal 2013; Bauer and Ege 2016). Organizational structures that provide for more local input may be crucial for project performance. Honig (2015) shows that such features have a strong impact precisely when local conditions are highly unpredictable, for example in fragile states. Trondal (2013) shows that organization by purpose engenders a logic of portfolio, while organization by process engenders a logic of hierarchy, and both behavioral logics have different implications on performance. However, demonstrating that organizational structure influences autonomy faces the challenge of endogeneity, which might exist because states design institutions rationally with a view to desired outcomes (e.g., Abbott and Snidal 1998; Koremenos, Lipson, and Snidal 2001). Nonetheless, organizational theory is useful as it can inform the debate on the determinants of institutional design. Budgetary pressure may lead to reorganization and specifically more centralization in the budget procedure, whether it was anticipated by the principal or not (Goetz and Patz 2016). More generally, there is a debate on the determinants of (de)centralization. For instance, agencies may centralize to avoid 
"siloization" and hence facilitate the flow of information across functionally specialized units (Trondal 2012: 435). Conversely, decentralization may reap the benefits of functional specialization. Considering the insights from organizational theory, I will argue that the institutional arrangement of pass-on funds follows a functional logic.

\section{Potential explanations for pass-on funds}

The puzzle of pass-on funds has two parts, one on the existence of pass-on funds and the other on their timing. For the static part of the puzzle, I draw on a functionalist argument. For the dynamic part, I take the principal-agent framework as a point of departure, discussing both donor-centered explanations and an agency-centered explanation.

Consider the question why pass-on funds exist at all. Certain units have comparative advantages in certain tasks and hence specialize in those; for example, sector units have expertise in global themes, and country units have unique country knowledge. These facts alone might explain why each type of unit raises its own funds in their relevant area of expertise, but they cannot explain the division of labor in pass-on funds. Organizational theory suggests that the process-driven allocation of responsibilities establishes hierarchy (Trondal 2013). Arguably, such hierarchy will only be acceptable in the presence of mutual benefits: Sector staff have better access to global funding than regional units and regional units have better capacities for implementation than sector units. ${ }^{6}$

In the timing of the rise of pass-on funds, two perspectives can be distinguished within the principal-agent framework. While the donor perspective relates pass-on funds to specific donor motivations, the agent perspective emphasizes the multilateral bureaucracy's motivations. From the donor perspective, one potential explanation for pass-on funds relates to the collective desire to increase control over the bureaucratic agent. Theoretically, unfaithfulness of the agent is a risk of delegation (e.g., Niskanen 1973; Vaubel 1986; Dunleavy 1991), and agent control mechanisms abound (e.g., Nielson and Tierney 2003; Lake and McCubbins 2006; Dijkstra 2015; Parizek 2016). Empirically, the creation of the Global Fund (to Fight Aids, Tuberculosis, and Malaria) can be rationalized by the desire of the donors to control the World Health Organization (Sridhar and Woods 2013). By analogy, one could ar-

\footnotetext{
${ }^{6}$ I am grateful to an anonymous reviewer for suggesting the idea of functional differentiation.
} 
gue that a pass-on fund is a control mechanism that relies on the disciplining effect of competition for funds. This strategy suggests that principals could create one big thematic fund and let country offices compete with good projects rather than delegating authority directly to country offices. For this control mechanism to be effective, donors would need to replace direct delegation to country offices (which is also difficult to screen) with indirect delegation via pass-on funds. An observable implication of this mechanism would be a structural break in the number of own funds or even a reduction in the number of own funds hosted at the regional units. However, available evidence suggests the contrary. Own funds in the regional units have continued to grow, even after the emergence of pass-on funds (see Web Appendix B2).

Another donor-centered explanation relies on preference divergence within the collective principal. By using pass-on funds, a donor with diverging preferences can reinforce a specific sector in which it has a salient interest and which the hosting unit addresses through the trust fund. While the donor actually aims at gaining leverage in the intergovernmental policy discussions, a by-product of its strategy is the empowerment of a specific sector unit inside the agency. This mechanism has two observable implications. One would be a similar rise in the number of own funds in the relevant sector units that are being empowered. Another would be a positive relationship between measures of salient donor interest in a given sector and the number of pass-on funds in the same sector. The available evidence for these implications is limited though. The growth of own funds in the network units started in the mid-1990s and halted in FY 2003 (see Figure B1 in Web Appendix B2). Moreover, there appears to be no robust relationship between trust fund membership and chairmanship in the relevant working group at the Organization for Economic Cooperation and Development (Reinsberg, Michaelowa, and Knack 2016). ${ }^{7}$

From a multilateral agency perspective, pass-on funds may be a result of "defunct delegation." This possibility follows the recent turn in principal-agent studies to focus on the behavior of the principals. Defunct delegation can occur in cases of principal shirking, principal drift, and principal subversion - opportunistic behavior by individual members of the collective principal (Elsig 2011: 498). For example, principal shirking occurs when member states do not pay their dues. This is a pri-

\footnotetext{
7 The case may be different for preference divergence on recipient countries. Such divergence may lead to more country-specific funds. Note however that a minority of trust funds have a prespecified target country.
} 
mary concern for agencies because their survival depends on financial contributions (e.g., Pfeffer and Salancik 1978; Barnett and Coleman 2005; Vaubel 2006). The other two defects are equally intimidating because they may reduce the perceived legitimacy of the agent, which is required to ensure the long-term viability of the agency (e.g., Haas 1964; Suchman 1995; Weaver 2007). For these reasons, the agent will respond to these defects because they threaten its autonomy. It is well known that not only states shape the environment for multilateral agencies but also certain multilaterals sometimes define the environment for states (Brechin and Ness 2013; Johnson 2014; Johnson and Urpelainen 2014). To regain autonomy, agencies can diversify their resource base (Reinalda and Verbeek 2004: 232), build alliances with non-state actors (Hawkins and Jacoby 2006), and form cartels with some competitors (Vaubel 1986), while reducing resource flows to other direct competitors (Posner 2009).

Someone must act on behalf of the agency. If agencies are assumed to be unitary actors, who acts does not matter, but a high level of actorness is required. This makes unitary-actor explanations for the emergence of pass-on funds unlikely, as there would need to be a corresponding authoritative decision by someone who represents the agency. There is no evidence of such decision. A more plausible explanation can be formulated if multilateral agencies are understood as collective agents (e.g., Barnett and Finnemore 2004; Weaver 2008; Graham 2013). In that case, pass-on funds emerge as the product of an interaction between different units. Each unit faces incentives to perpetuate the implied division of labor - network units raising funds and managing the programs, and regional units implementing them. Supportive evidence would need to identify the changing circumstances that render these funds profitable for both units.

My above discussion suggests that agency-centered explanations for pass-on funds are a priori more convincing than donor-centered explanations, especially when considering pass-on funds as the result of individual optimizing decisions of different units rather than the planned response of the agency leadership. In summary, my favorite explanation has two parts. The static part uses the functionalist argument that pass-on funds are an efficient way to divide the labor based on a process logic. The dynamic part builds on the public-choice argument that individual units struggle for their autonomy, and argues that both units faced changes in their environment that rendered pass-on funds profitable to them.

In the following section, I provide empirical support for my theoretical explanation. Given that the rise of pass-on funds at the World Bank is a singular event, 
I need to rely on qualitative evidence. Specifically, I draw on semi-structured staff interviews at World Bank headquarters during summer 2013, with a few follow-up interviews in 2014. ${ }^{8}$ Complementary data include documents such as trust fund program documents, annual budget reports, and evaluation studies.

Web Appendix A includes a quantitative analysis of determinants underlying the use of pass-on funds, based on a formal bargaining model between a network unit and a regional unit. The results provide further statistical evidence suggesting that the struggle for autonomy of individual units (as proxied by their budgets) and external constraints facing the units are the factors driving the use of pass-on funds. The statistical analysis supports my claims regarding the incentives underpinning passon funds, but does not generate qualitatively new insights, and therefore appears in the Web Appendix.

\section{Empirical analysis}

The evidence presented in this paper draws on the case of the World Bank. Following an introduction to its institutional structure, the subsequent parts of the analysis address the research questions of this paper - the rationale for pass-on funds and factors driving their timing.

\subsection{Organizational reforms at the World Bank}

The World Bank is a multilateral agency that promotes development mainly through the International Bank for Reconstruction and Development (IBRD) and the International Development Association (IDA). Multilateral policies are broadly determined by the member states, which convene every three years in the Board of Governors, and on a regular basis in the Board of Executive Directors. The Board of Executive Directors approves the IBRD/IDA projects as prepared by Bank staff.

The World Bank bureaucracy includes a president (appointed by the member states) and over 10,000 staff in headquarters and country offices. It has a complex structure that changed a few times in recent history. A persistent feature of the World Bank has been the so-called "matrix structure," existing since 1987. Since then no institutional reform - not even the latest one in 2014 — touched this constitutive feature (see Web Appendix B1 for details on organizational reforms at

\footnotetext{
${ }^{8}$ An anonymized list of all 80 interviews is available from the author upon request.
} 
Figure 3: A simplified representation of the "matrix structure"

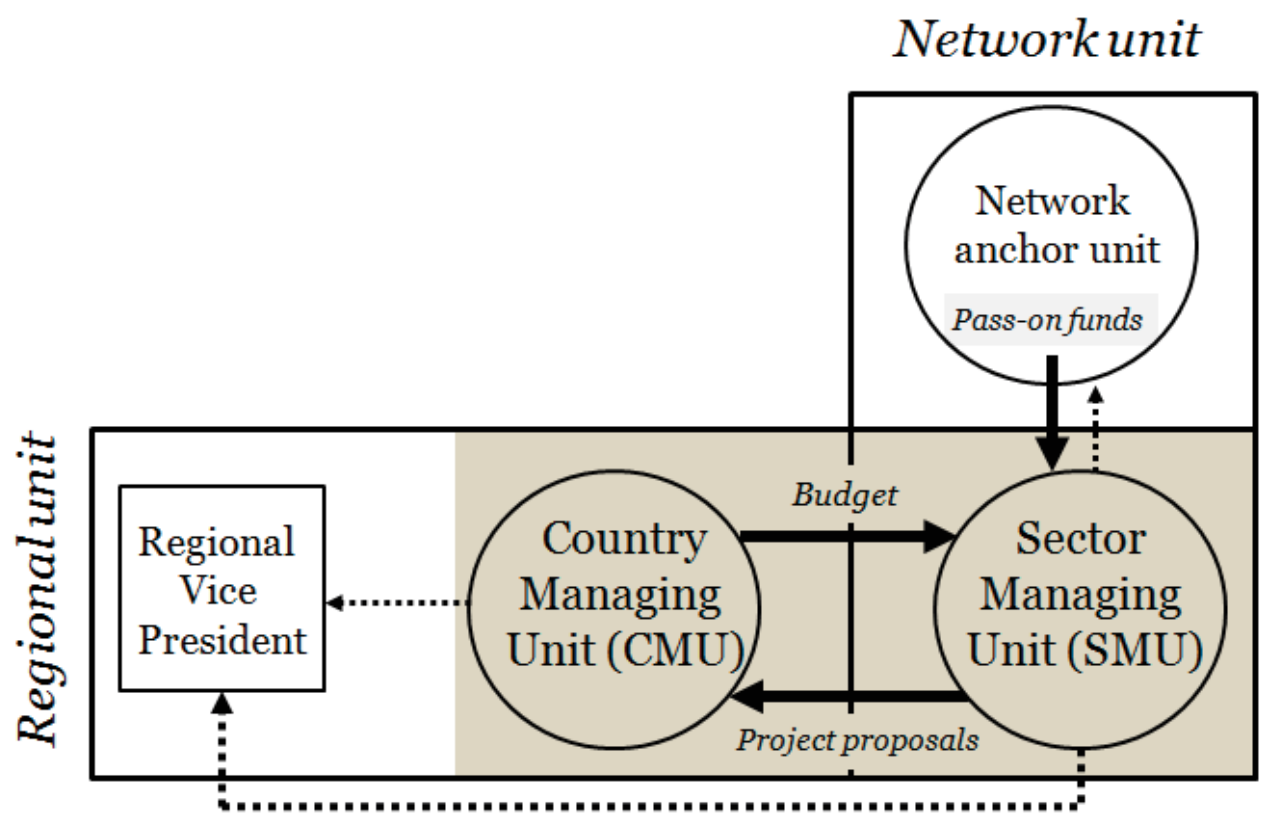

Notes: This simplified structure shows the interaction between one CMU and SMU (and higher hierarchical levels). Blank areas correspond to headquarters, and gray-shaded areas indicate the country level. Dotted lines reflect accountability relationships.

the World Bank).

The matrix structure governs the interactions of two functionally specialized types of units in each of the six regional Vice Presidential Units (VPUs) of the World Bank (Figure 3). In each regional unit, headed by a regional Vice President, there are several Country Managing Units (CMUs), headed by country directors, and Sector Managing Units (SMUs), headed by sector directors. While CMUs are responsible for the overall country strategy, SMUs cover all technical aspects of project design for a group of countries.

A matrix structure has the benefit of functional differentiation, where CMUs develop expertise in convening services and managing portfolios, and SMUs develop expertise on technical aspects of individual projects. As a result, regional units can be expected to deliver quality projects also relevant for country needs. A disadvantage of the matrix structure is the risk that projects may not fully benefit from global knowledge at the sector level, because SMUs work in their respective country departments without sufficient access to sector-specific knowledge at the global level.

"Network anchors" are sector-wide knowledge hubs detached from individual regions, which collate sector-specific knowledge at the global level. They somewhat 
alleviate problems of "siloization." The World Bank introduced network anchors in its FY 1997 reform (also known as the "Strategic Compact"). Since mid-2014, following the latest organizational reform, the network anchors no longer exist formally, and the sector-specific global work is carried out by hierarchically organized network units called "Global Practices." As the new Global Practices have their own heads (rather than a Sector Board governing network affairs collectively), network units are more powerfully represented than regional units in the new structure with the goal of enhanced Bank-wide learning (Stoiljkovic and Hansen 2014).

None of the most recent institutional changes alters key organizational features established by the Strategic Compact. One such key feature is the coexistence of CMUs and SMUs in any given regional unit and the dual accountability of SMUs to regional and network heads. Moreover, there is continuity with respect to passon funds, which continue to be administered by network units at headquarter level while being routed through SMUs for implementation.

\subsection{The rationale for pass-on funds}

\section{The demand side of pass-on funds}

Pass-on funds allow regional units (CMUs and SMUs) to expand their activities. Pass-on funds are very flexible because they can provide program funding to support recipient-executed activities while also covering expenses for staff activities related to project preparation, appraisal, and supervision. In the former case, pass-on funds are similar to IBRD/IDA resources while involving a potentially higher degree of concessionality to the recipient country. Trust funds are always grants, IDA funding includes concessional loans and grants, and IBRD loans are non-concessional. By "sweetening the deal" for recipient countries, trust funds enable CMUs to boost their lending operations by giving countries the capacity to borrow and easing the terms of Bank assistance. For example, "[i]n Indonesia, which is reluctant to borrow IBRD funds for technical assistance, as much as $23 \%$ of the trust fund portfolio is dedicated to such work [...]" (IEG 2011: 36). In addition, thematic funds often provide funding for global public goods and thereby provide country staff with increased access to government officials with whom they did not interact beforehand, hence increasing the potential for new projects. Indeed, pass-on fund grants are " [...] an incentive to trigger internal actions within countries and also provide the Bank with a way to 
engage with line ministries in middle-income countries" (IEG 2011: 35). ${ }^{9}$

Besides financing recipient-executed activities, pass-on funds are a substitute for the administrative budget. An important example is the Policy and Human Resources Development (PHRD) trust fund. Supported by Japan and housed by the Concessional Finance and Partnerships unit, the trust fund provides resources to develop lending projects and to enhance their quality. As stated in its annual report, "[p]roject success can often be related to the [...] solid project preparation, which would not have been possible without PHRD support" (PHRD 2012: 8). In one project discussed in the report, "the PHRD grant was instrumental in the preparation and approval [...] by the World Bank Board of Executive Directors" (PHRD 2012: 10). The quote demonstrates that an individual project preparation grant may be valuable, and pass-on funds are more likely to supply these grants than other trust funds (see Figure 4). When pass-on funds finance analytical work that at first sight does not seem to be useful for regional units, they may still be beneficial because those funds are "[...] sometimes fungible when paying for staff designated to work on the implementation of Bank projects." If they do so, "there are pressures to access trust funds for economic and sector work [...] in order to preserve Bank budget for project appraisal and supervision" (IEG 2011: 75).

The considerable benefits that pass-on funds accrue to regional units may still not be enough to explain their actual use. Could a regional unit not realize these benefits by raising its own funds? To be sure, by raising its own funds, a unit can often well align the fund with its own priorities. However, there are limits as to which impacts these trust funds can achieve. Own funds in the regional units often co-finance individual projects, often with the support of a single donor. Apart from a few single-recipient flagship funds such as the Afghanistan Reconstruction Trust Fund (ARTF), these regional funds tend to be hardly visible for the larger donor community and hence do not attract huge amounts of contributions. If a regional unit decides to raise its own fund, it also faces administrative costs due to the maintenance of donor relations and trust fund secretariat services, which may overburden the capacities especially of the smaller units. Finally, country directors often are unable to access those donor officials in the donor capitals who make significant aid budget decisions. Therefore, pass-on funds may be a better option under some

\footnotetext{
${ }^{9}$ Trust funds for global public goods reach new beneficiary countries because these countries often have no need for development assistance on national public goods, but they supply global public goods most efficiently (see also, Bagchi, Castro, and Michaelowa 2016).
} 
circumstances. They often mobilize large amounts of resources for specific themes that may also be relevant in a given recipient country. Their global scope increases attention from a larger pool of donors, which implies larger fund sizes. Indeed, global funds on average are five times larger than country-specific funds, soliciting contributions of about USD 200 million per fund - this difference is strongly statistically significant (calculations based on World Bank 2013h). This provides the case for pass-on funds as an additional funding mechanism besides own funds. In addition, own funds often do not provide (enough) funding for purposes such as project preparation. Half of all grants from own funds co-finance country operations, while pass-on funds concentrate most of their grants on technical assistance, followed by co-financing and project preparation (Figure 4).

Figure 4: Purposes of pass-on funds and own funds in the regional units

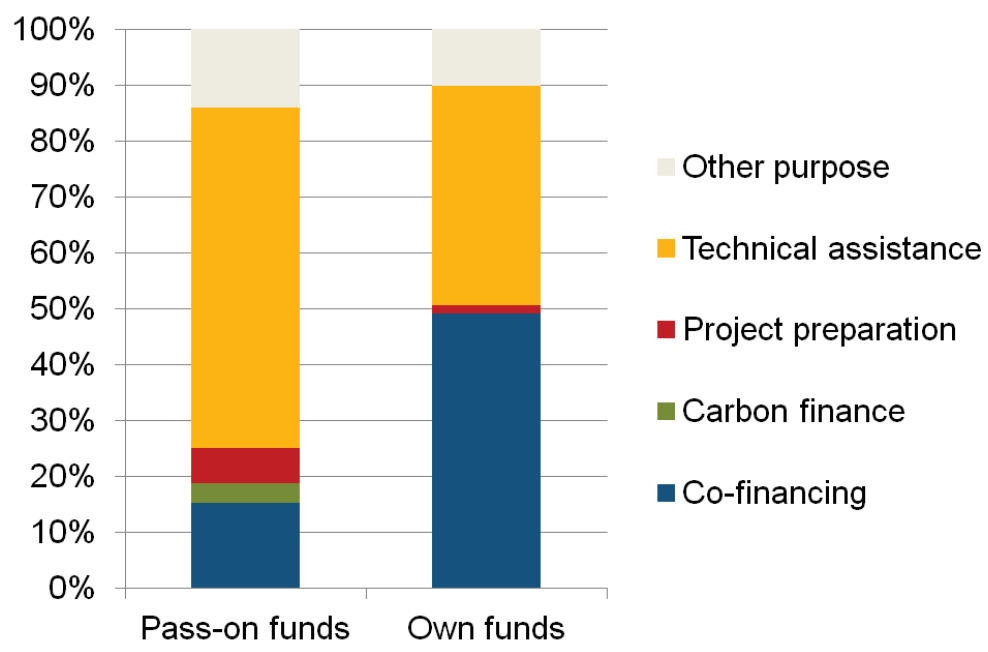

Notes: Purposes of trust fund in the regional units by origin of funds - pass-on funds versus own funds, based on the number of grants between FY 2003-12. Other purposes not shown include administrative funds, consultancies, debt service, financial intermediation, and other innovative financing.

Source: World Bank (2013g)

However, pass-on funds are not costless to the regional users, especially to CMUs. The funds creep into the autonomy of regional units by altering the sector composition of their country activities. This drawback becomes particularly salient when the pass-on funds support sector activities that are not a priority for the CMU and its recipient government. The Independent Evaluation Group (IEG) states that "[...] while virtually all of the trust-funded technical assistance and economic and sector work deals with issues relevant to the country, the work is not always of the highest priority, would not have been done using the Bank's budget, and does not always 
receive management attention and quality assurance [...]" (IEG 2011: 37). In fact, "[i]t is staff in those sectors that are crowded out of the CAS [Country Assistance Strategy] or who do not accept that theirs is not a sector expected to feature active Bank engagement in the country who then go looking for trust-fund funding (since this is not made available by the CMU). It is this sort of entrepreneurial activity that leaves counterparts complaining about studies not relevant to the country and studies that lie outside donor coordination mechanisms" (IEG 2011: 37). Another manager asked for an IEG study criticized the Carbon Funds — for causing "[...] a thousand flowers to bloom," and that the funds have become "an operational mess, supporting things that we should not be doing" (IEG 2011: 36). During my own interviews, one official gave an example of a study intended to advance the knowledge base of a global sector fund, but it turned out that it did not have any concrete value to the client country. ${ }^{10}$ The intrusion of pass-on funds into country priorities clearly is a significant challenge. ${ }^{11}$

A related concern refers to the potentially adverse quality implications of passon fund activities. Since the funds do not align well with regional units' priorities, regional managers tend to neglect quality control. Several interviewees highlighted this problem. For example, one Operations Officer explained that there is "de-facto a problem of ownership [...]" and a "higher chance of disconnect and that certain people are not put in the loops." 12 A regional Trust Fund Coordinator claimed: "In our unit, all trust fund projects must be approved through the country director [...], including the funding applications for pass-on funds," adding that "other regional units do not necessarily have such rules." ${ }^{13}$ My evidence on lack of ownership of pass-on funds also bears out in the IEG evaluation. According to the evaluators, supervision quality remains low because the country unit has little ownership in these funds, arguing that "[...] the smaller funds, especially those managed by the networks, seem to be 'off the radar screen' of the country management unit once they are approved" (IEG 2011: 61).

A final problem yet unmentioned refers to transaction costs. The same Trust Fund Coordinator whose unit had strict senior approval rules argued that a task team leader may submit and application "but does not automatically get the funding,"

\footnotetext{
${ }^{10}$ Interview with Social Development Specialist (August 24, 2014)

11 Sometimes units may still accept pass-on funds for poorly aligned research studies because some (not all) SMU staff get prestige and psychic benefits from getting published. The testable empirical implication would be that these staff members should be less sensitive to misalignment.

12 Interview with Operations Officer from a Central Unit (August 12, 2013)

13 Interview with Trust Fund Coordinator (August 14, 2013)
} 
suggesting that pass-on funds may create costs to the regions even when they do not support any operation. This echoes earlier work showing that trust funds increase internal fundraising costs for World Bank units (Reinsberg 2016). ${ }^{14}$

\section{The supply side of pass-on funds}

Network anchors benefit from pass-on funds for at least two reasons. The first is that these funds tend to be sizable and therefore generate significant fee income that a network can use to pursue its priority activities independently from country demand (World Bank 2007a: 4). If network staff attract funds from donors, they obtain tangible rewards (such as pay rises and job promotions) from becoming more operationally relevant and psychic rewards from being operationally relevant and not just a anchor unit bureaucrat. The second reason is that thematic funds allow network staff to promote their specific thematic interests, even if a sector is not of greatest priority to country units. Pass-on funds therefore enable network units to tilt the portfolios of regional activities toward their own preferred sectors. In addition, they also involve co-benefits for network units themselves by supporting their analytical work at the global level. ${ }^{15}$

While network anchors are motivated to raise pass-on funds, they are also best placed to solicit large trust funds for global themes from bilateral donors. Donor officials who are interested in particular sectors do not reach out to the field but rather to network staff in Bank headquarters. For a donor, making a network anchor the sole point of contact for a global fund can (1) reduce its transactions costs, and incidentally the Banks - the minimum size requirement may even force it to provide one larger TF instead of several region- or country-specific trust funds; (2) use the network anchors expertise - the donor may trust it to use the funds efficiently more than it trusts anyone else to; (3) ensure cross-border costs and benefits are taken into account that CMUs might ignore. ${ }^{16}$

Network staff at the Bank can thus present themselves as the natural interlocutors for donor representatives in donor countries' capitals. As one Trust Fund Coordinator from a large network unit explained: "There is a headquarter advantage in terms of capacities and preferences. We are based in D.C. [...] other VPUs

\footnotetext{
${ }^{14}$ In reality, however, CMU staff may still have lower transaction costs from dealing with pass-on fund staff than external donor staff. I thank Stephen Knack for highlighting this point.

${ }^{15}$ Co-benefits are reflected in the Bank-executed funding items within pass-on trust funds and are quite significant (own calculations, based on World Bank 2013g).

${ }^{16}$ I am grateful to Stephen Knack for mentioning these three issues.
} 
have regional offices, so they often do not have the capacity and the incentive to negotiate hard with donors." ${ }^{17}$ In their effort to raise new pass-on funds, networks are most likely to focus on bilateral donors with large global budgets, donors that share their sector interests, and larger donor countries which tend to have broad country lists. ${ }^{18}$

A glance at the contribution data for pass-on funds supports these claims. In terms of cumulative contributions over FY 2002-13, the four most important donors of pass-on funds were the United Kingdom, Norway, the Netherlands, and Spain. Engagement strategies vary considerably across these donors: The United Kingdom and the Netherlands also have vast country-specific contributions and hence are the primary financiers of regional units' own funds. Their contribution shares to pass-on funds are below 20\%. In contrast, Norway and Spain are most engaged in pass-on funds as compared to the other donor countries. This squares well with the common wisdom that these two countries have salient sector interests and thereby prefer to ally with the network units at the World Bank. For example, Spain created a "MDG Achievement Fund" at the United Nations to help advance social development in 2007. Also, Norway has strong interests in themes like gender equality, good governance, and human rights. ${ }^{19}$

In the same way as pass-on funds involve challenges for regional users, they may also be a risk for the network units which own them. One Program Officer of a well-established global program stated that "country directors do not look what is best for the program [...]" 20 - implying that they are rather concerned with aligning trust funds and Country Assistance Strategies. Asked about the most likely implications of pass-on funds, a Controller argued that these funds could improve internal cooperation, although communication across departments could sometimes be burdensome. ${ }^{21}$

In summary, the analysis thus far lends support to the functionalist argument that pass-on funds and their underlying division of labor are efficient as they reflect the respective comparative advantages of each type of unit. Network anchors hosts the funds as they are better able to access global donor resources, while regional units have implementing expertise at local levels. This division of tasks along the main

\footnotetext{
17 Interview with Trust Fund Coordinator from a network unit (July 23, 2013)

18 Interview with Senior Operations Officer (August 28, 2013)

19 Interviews with Trust Fund Manager (July 26, 2013), Coordinator (July 26, 2013), and Senior Program Coordinator (August 19, 2013)

20 Interview with Program Officer (August 9, 2013)

${ }^{21}$ Interview with Operations Officer (July 30, 2013)
} 
processes creates a new hierarchy in which networks gain authority over regions. For the World Bank as a whole, the funds only seem beneficial when they align with country priorities and hence avoid problems of insufficient ownership on the part of regional users.

\subsection{Organizational reform and the rise of pass-on funds}

\section{Organizational reform threatened the autonomy of sector units}

Yet to be explored are the particular factors that drove the sudden explosion of passon funds around the millennium. In fact, the adoption of the Strategic Compact and the rise of pass-on funds are not coincidental. As argued below, the Strategic Compact can be seen as the single most important explanation for the rise of trust funds. The adoption of the reform followed a series of setbacks for the World Bank in its relations with the external environment since the end of the Cold War. In particular, a key concern was the technical quality of its project work. An internal evaluation of the matrix structure stated that "technical staff worked primarily in country department silos and the technical quality of $[. .$.$] project work dete-$ riorated" (World Bank 2012a: 115). In addition, development projects were not always perceived as relevant for country needs. An influential report accused the Bank of a "pervasive lending culture" (Wapenhans 1992: 12). The Bank also was perceived as losing sight of the poor (Smyth 2011: 983) and as sluggish in responding to new demands from donors, but arguably these demands proliferated after the end of the Cold War (Weaver 2007: 500). Major donors lost its faith in the Bank and threatened to withhold contributions unless Bank management implemented organizational reforms (Thibodeau 1996).

To address these concerns, the World Bank under the leadership of president James Wolfensohn launched a three-year reform program dubbed the "Strategic Compact" in 1997. The reform expedited the devolution of country activities to the field. In addition, it aimed at reinvigorating the organization as a "knowledge bank" to better reflect the development needs in the globalization era. To achieve the goal of a knowledge bank and more specifically to facilitate Bank-wide learning, the reform established so-called "network anchors" and sector boards to link all SMUs across the Bank and hence make available global knowledge to country teams. In addition, the reform established dual reporting relationships and country budgets allocated by CMUs to different SMUs. After the restructuring, it was no longer possible for SMUs to deploy budget resources without approval by CMUs, which 
sought to reduce "supply-driven behavior" by SMUs, hence aligning World Bank operations more closely with country demand (World Bank 2001).

The World Bank itself recognized the significance of this specific feature of the reform. According to an internal report, "it is this feature, and not the creation of the networks $[\ldots]$, or decentralization," that makes the reform "qualitatively different from those that came earlier" (World Bank 2012a: 116). The transfer of budget autonomy into the hands of CMUs posed a threat to the autonomy of SMUs. As one experienced official put it: "Why should CMUs buy expert knowledge from the SMUs?" - obviously, SMUs remain collectively relevant as providers of sector expertise, but not an individual SMU whose sector is no longer deemed relevant by a given CMU. Therefore, according to the official, while the historical division between CMUs and SMUs is reasonable, it translates into "budget fights." The consequence of budget pressure on the SMUs was that SMUs developed additional resources through trust funds. But this bears the risk of "satellite operations," activities not aligned with Country Assistance Strategies, without "the Country Director knowing about trust fund missions in the country." ${ }^{22}$

According to another official, sector staff "were desperately looking for their sense of being." As a result, "a pathological trust fund culture emerged, where TTLs [task team leaders] chased even after ten thousand dollars and labeled this a great success for their cause." 23 This echoes statements in the IEG evaluation report that individual staff members were shopping around for trust fund monies, oftentimes leading to studies that were not considered as relevant for country needs (IEG 2011: 37).

\section{Network anchors start filling resource gaps for sector units}

At the same time as SMUs lost their budget autonomy, their global pendants the newly established "network anchors" — started raising large funds for thematic priorities. These funds provided SMUs with an opportunity to tap new resources independent of the demand from CMUs. As the funds were formally hosted by network anchors but passed on to SMUs for local projects, they are called "pass-on funds." As a consequence of pass-on funds, the authority of network units (and the autonomy of SMUs vis-à-vis CMUs) inside the World Bank increased.

The networks could monetize on the increased donor attention toward social de-

\footnotetext{
${ }^{22}$ Interview with Trust Fund Coordinator (August 23, 2013)

${ }^{23}$ Interview with Social Development Specialist (August 24, 2014)
} 
velopment since the Millennium Declaration, adopted in September 2000. Allying with sector specialists in donor capitals, network staff mobilized "huge buckets of money." 24 This statement from a Trust Fund Coordinator can be further substantiated by a look at the bilateral aid allocations of the ten largest donors of trust funds. Without suggesting a one-to-one relationship between the bilateral aid allocations and trust fund contributions, it is still remarkable that bilateral funding for global purposes became more abundant since the mid-1990s. In the four years between 1997 and 2000 only, global-purpose aid more than doubled. Thereafter, funding volumes fluctuated around USD 8 billion. Key donors that expanded their global allocations around that time were Germany, the Netherlands, the United States, and also the European Commission. ${ }^{25}$ Suggesting a growing awareness among donors for global issues, these figures hence illustrate that the network units seized a unique opportunity to build up their trust-funded chiefdoms for global themes. An internal report reaches a similar conclusion, arguing that the newly created network anchors served the growing demand for sector-specific global development expertise, though this was not at all foreseen at the time the Strategic Compact was conceived (World Bank 2012a: 119).

\section{Organizational reform created demand for pass-on funds}

A number of features in the Strategic Compact also led to incentives for CMUs to use pass-on funds to support their operations. In fact, CMUs became ever less resistant against pass-on funds because nearly all features of the reform increased the pressure on their administrative budgets.

Administrative budgets are indispensable for delivering development projects. In particular, the administrative budgets covers Bank expenditure related to project preparation (prior to approval by the Board), and project supervision (once the projects are activated). Three features of the Strategic Compact squeezed administrative budgets: increasing safeguard requirements, the evolution of country portfolios toward high-cost environments, and the increasing devolution of country activities. I discuss each of them in turn.

First, since the mid-1990s, projects involved growing exigencies on safeguards. As one project manager explained for an IEG review: "I have plenty of examples of technical specialists that I have not been able to bring on mission [...] because

\footnotetext{
${ }^{24}$ Interview with Trust Fund Coordinator from a regional unit (August 2, 2013)

${ }^{25}$ For EU aid through trust funds, see also, Michaelowa, Reinsberg, and Schneider (2016)
} 
there is no money in my supervision budget after hiring fiduciary, procurement, and safeguard specialists [...]," while other respondents confirmed that on supervision missions "compliance specialists" tend to crowd out sector specialists (IEG 2014: 49). The reason for these elevated requirements was a consequence of a series of alleged failures since the late 1980s. In 1991, the Bank had to revamp its environmental safeguards following United States pressure and protests from environmentalists in the realm of the Narmada dam project in India (Weaver 2008: 23). Later, the Bank also revised its social-economic safeguards, responding to criticism on the alleged failure of "structural adjustment policies" (Danaher 1994; Weaver 2008; Jolly 2014).

Second, regional units also faced higher costs as they engaged in more difficult country contexts, notably post-conflict states (World Bank 2005b: 35), which need a lot of technical assistance without offering the immediate prospect of taking up a loan from the Bank. After the end of the Cold War and the related shift in donor motives in aid allocation, the World Bank also committed to direct IDA funding toward poorer clients and to Africa, which "resulted in faster growth of expenditures" (World Bank 2005b: 38).

Finally, following accusations of a pervasive "lending culture" (Wapenhans 1992: 12), the World Bank reorganized its operations and devolved country operations to the field. While in FY 1996, not a single country director was located in the field, already three quarters of the country directors were dislocated to the field in FY 2005 (World Bank 2005b: 34). The built-up of local infrastructure was costly, which reduced the administrative budget being available for other purposes. In the spirit of the Paris Declaration, the Bank also sought to increase country ownership through "greater participation in formulating country development assistance strategies," which likewise increased costs for the regional units to be covered from their administrative budgets (World Bank 2005b: 33).

In light of these challenges, regional units were less reluctant than ever before to turn to pass-on funds in the hope for additional resources. Raising their own trust funds at the field level was no alternative because such funds primarily co-finance program activities and thus cannot be used for technical assistance and project preparation.

In summary, my case study has established the rationale for pass-on funds in general and related their sudden rise to the organizational reforms of the Strategic Compact. As argued more generally in an IEG report, "[a]ccording to the vast majority of those interviewed, budget constraints are [...] perhaps the most important 
reason why staff pursue trust funds. They referred to 'the budget squeeze,' the work program 'increasing tremendously while the Bank budget has remained flat,' and the risk that their unit "would be out of business without trust funds"' (IEG 2011: 75). Organizational reform and budget pressures are not mutually exclusive explanations. The reform can be seen as the trigger for the sudden emergence of pass-on funds, and the effect of the reform worked mainly through its budgetary implications for the two units involved. For the SMUs, the reform took away their independent budgets and hence made them seek out new funding opportunities, notably the individual grants from pass-on funds. This partially restored their sense of being. CMUs were ever less reluctant to accept the intrusion of pass-on funds into their programs While the regional units were able to expand their work program, because the reform entailed features that squeezed their own administrative budgets and hence pass-on funds promised to ease this constraint.

\section{Theoretical implications}

Given the novelty of pass-on funds and their rapid growth over the past decade, the primary motivation for this paper is empirical. However, pass-on funds raise interesting theoretical questions regarding the functional differentiation of international bureaucracies and the kinds of incentives facing different bureaucratic actors. Following previous studies on trust funds, my subsequent discussion focuses on potential lessons within the principal-agent framework.

With respect to the emergent literature on trust funds, my analysis provides a complementary perspective to most existing studies that focus on the donor perspective (e.g., Sridhar and Woods 2013; Graham 2015; Eichenauer and Reinsberg 2017). An exclusive donor perspective may not be fruitful when trying to explain intra-organizational patterns of authority as implied by pass-on funds. In fact, there is no clear evidence that pass-on funds directly relate to interests among the principals, neither due to a collective desire to gain control over the agent nor due to preference divergence among the principals.

While the focus on the agent holds much promise, it is further necessary to disaggregate the agent. To my knowledge, only one study in the principal-agent framework examines the implications of a fragmented agent on its overall faithfulness (Graham 2013). Moreover, autonomy is often thought to refer to the principal-agent relationship. However, struggles for autonomy exist within collective agents. My case study of pass-on funds shows that different units must cater to different needs 
- CMUs take the local needs into account, while network units think globally and promote specific themes without necessarily appreciating local circumstances. For an actor to be autonomous, having an autonomous will is not enough - autonomous resources are required to pursue autonomous preferences (Cortell and Peterson 2006; Caughey et al. 2009; Bauer and Ege 2016). As pass-on funds give budget authority to network units and hence potentially reduce the policy discretion of CMUs, the decision for CMUs whether to accept pass-on funding is not unconditional. The tradeoffs of pass-on funds only become clear when considering autonomy between individual units inside the multilateral bureaucracy rather than autonomy between the entire bureaucracy and its member states.

My case analysis also echo recent arguments that unfaithful principals rather than unfaithful agents may be responsible for changes in organizational behavior (Elsig 2011). The case study has offered some evidence of principal shirking: The threat of some powerful donors to withhold core contributions was a key motivation for World Bank president James Wolfensohn to launch the Strategic Compact (Weaver 2008: 22) that triggered the observed dynamic of pass-on funds through its implications on administrative budgets. Moreover, there is evidence of principal drift: The growing demands on the World Bank were not matched with corresponding increases in resources (Linn 1998), leading to growing frustration by donors about lack of progress (Smyth 2011: 983); this likely expedited the organizational reform. Finally, there is evidence of principal subversion: Some donors openly challenged the collective consensus and pushed the Bank into new areas, as evidenced by the Bank-Netherlands Partnership Program and the activities of the Nordic countries in the area of human rights (see also, Reinsberg, Michaelowa, and Eichenauer 2015; Reinsberg, Michaelowa, and Knack 2016; Reinsberg 2016).

\section{Conclusion}

Over the past two decades, earmarked funding to international development organizations has grown massively. The financial mechanism through which external donors contribute these earmarked resources are so-called trust funds. The World Bank as possibly the most important trustee organization has a long-standing tradition in the management of trust funds that dates back to the 1960s. Until the mid-1990s, the prevailing type of trust funds were so-called "own funds," by which individual units in the multilateral bureaucracy raised trust funds to support their own work program. 
Since the turn of the millennium, however, a new type of trust funds has emerged. In so-called "pass-on funds," one unit hosts the trust fund while another unit inside the organization implements the individual activities under the trust fund. In the case of the World Bank, this division of labor has taken a characteristic shape: The so-called "network anchors," which exist only since an organizational reform in FY 1997, host large funds for global themes, for example fragile states, gender equality, and climate change, and pass them on for use in the "regional units" and their individual country offices.

Theoretically, the rise of pass-on funds reflects an interesting setting. The first question that I address in this paper is why these funds exist at all. Following organizational theory, my paper shows that this process-driven specialization reflects the respective comparative advantages of network units to access global funding sources and the regional units to implement projects on the ground. This is less trivial than it looks at first sight given that pass-on funds also establish a new hierarchy that puts regions at a disadvantage. Unlike "own funds," which match the priority issues of a unit, "pass-on funds" may lead to misalignment between global priorities (as promoted by the network anchor) and country-specific needs (as promoted by the regional unit and particularly the country office) (see also, IEG 2011: viii). As compared to own sources of funding, the regional unit hence faces a tradeoff between obtaining additional resources and staying relevant to country needs when deciding whether or not to accept pass-on funding.

A second question pertains to the timing of pass-on funds. Using evidence from semi-structured interviews at the World Bank and complementary document sources, I identify the Strategic Compact - a three-year organizational reform that reorganized budget authority between the relevant units - as the key driver of pass-on funds. On the one hand, the network units had a particular incentive to do so since the reform moved budget authority into the hands of country managers and thereby created pressures to regain budget autonomy among sector staff. At the same time, bilateral donors increased their funding for global themes, which was a unique opportunity for the network units to start building their own chiefdoms supported through these donor monies. On the other hand, regional units became more desperate for the project preparation budgets provided by pass-on funds as they saw their own administrative budgets decline as a result of costly devolution, a higher share of difficult countries in their portfolios, and increasing requirements on safeguards.

These findings can claim generalizability beyond the period under investigation 
and beyond the World Bank context with some minor adaptations. Since 1997, the bread-and-butter business of the World Bank — working with recipient countries and managing projects - operates under a matrix structure that intertwines country units and sector units and that gives budget authority to the country directors (World Bank 2012a: 111). In 2014, the World Bank underwent an organization reform that established Global Practices in an attempt to break the institutional primacy of the regions and encourage global learning within each sector. However, the reform did not alter the above matrix structure within each regional unit. Country directors continue to hold de-facto budget autonomy as their specific demands determine which sectors feature in country assistance strategies. The key feature that was created with the introduction of the 1997 reform therefore persists even under the revised structure. My own interviews suggest that staff do not perceive to be affected with respect to their incentives vis-à-vis trust funds. Therefore, the issue of pass-on funds remains acute, which implies a continued need to balance sector interests and country needs at the World Bank.

Beyond the World Bank case, my analysis may apply to a broader set of agencies. Though this paper is about the World Bank, its analysis is relevant beyond this specific case because the pass-on fund arrangement is common in all major functionally differentiated international organizations. Such large organizations consists of headquarters and field offices, each having different preferences (despite shared goals) and hence there is a struggle for autonomy and a need for bargaining. For example, one official from the International Labor Organization (ILO) privately said: "Rainmakers in the various multilateral agencies actively use the funds $[. .$.$] to position$ themselves and their departments and to build their careers." There hence seems to be the risk that trust funds become a strategic device by which individual units seek to enhance their position within a multilateral agency; actual relevance for recipientcountry needs, project quality, development impact, and cost effectiveness may get lost on the way. Future research may look into these issues, specifically also in a United Nations context where pass-on funds formally exist since the establishment of the Multi-Partner Trust Fund Office in 2003. ${ }^{26}$

My study also has potential applicability even beyond intra-organizational in-

\footnotetext{
26 The similarity of the pass-on funding context at the United Nations indeed is striking. In its inter-agency pooled funds, donor contributions are not a priori earmarked for a specific implementing agency, and decisions on program allocations are made by an administrator, usually the United Nations Development Program, "taking into account the programmatic purpose and results framework of the fund" (UNDG 2015: 4). Implementing agencies face an incentive to obtain additional resources, even at the risk that proposed activities do not match country priorities.
} 
teractions. The specific situation in which one agent hosts funds and another agent requests support from the funds occurs a lot in the multilateral development system, at least since the rise of so-called "multi-actor funds" (Heimans 2004), for example the Global Environment Facility, the GAVI Alliance, and the Global Fund to Fight Aids, Malaria and Tuberculosis. These multilateral institutions raise huge amounts of donor monies while not having own implementation structures. To implement their programs, these institutions rely on the established international development organizations, such as the World Bank and other bureaucracies. In these settings, my analysis can shed light on the conditions under which a given global fund chooses a specific implementing organization. Prominent research has already been done on the case of the Global Environment Facility (e.g., Bayer, Marcoux, and Urpelainen 2014), and this paper further contributes to this important strand of research. In an increasingly complex world plagued by many global problems, the division of labor among different multilateral organizations will further increase and hence these settings of inter-agency bargaining deserve closer attention.

From a theoretical perspective, the findings of this paper have immediate implications for the emerging literature on earmarked funding at international development organizations. Related studies forward donor-centric explanations for the emergence of earmarked contributions (e.g., Reinsberg, Michaelowa, and Eichenauer 2015; Graham 2015). In these studies, disagreement among the donors over the substantive activities of international organizations holds a key to explain earmarking patterns (e.g., Eichenauer and Hug 2015; Graham 2016; Reinsberg, Michaelowa, and Knack 2016).

While these studies have advanced the field in significant ways, this paper provides a complementary perspective by analyzing the incentives for multilateral agencies to pursue extra-budgetary funding through trust funds. The literature thus far has explored these incentives only for specific issue areas, for example Carbon Finance at the World Bank (Michaelowa and Michaelowa 2011). Most literature often does not question the unitary-actor assumption on the multilateral bureaucracy. This overlooks that different units may have different preferences and that they need independent resources to pursue these preferences. This echoes with public choice arguments that bureaucrats (here aggregated into cohesive units) have an incentive to grow their budgets in order to increase their autonomy. As an important caveat, however, this autonomy is defined with respect to competing units, not with respect to the principal, as usual within principal-agent studies.

In a broader view, the paper reinforces arguments about the active role of bu- 
reaucrats in institutional design (Johnson 2014), given that the creation of trust funds can be seen as such an instance of institutional design led by bureaucratic entrepreneurs. My work shows that bureaucratic influence on institutional design may itself be the result of a strategic interaction between organizational units. Hence, the set of scope conditions under which we see bureaucrats to enter the design stage may need to be extended to also include factors such as resource competition, thematic alignment, and inter-unit trust, in addition to factors that focus more on the interests of member states.

Within studies of bureaucratic politics and intra-organizational bargaining, more research could be done to integrate the donors as a strategic actor, without sacrificing the heterogeneous actor perspective on multilateral agencies. More specifically for the case of the World Bank, an open issue refers to the rise of own funds as evident from the descriptive statistics and how it relates to the rise of pass-on funds. This issue was deliberately left aside in this paper but it would be worthwhile to look into this at greater detail. 


\section{References}

Abbott, K. W., \& Snidal, D. (1998). Why states act through formal international organizations. Journal of Conflict Resolution, 42(1), 3-32.

Bagchi, C., Castro, P., \& Michaelowa, K. (2016). Donor accountability reconsidered: Aid allocation in the age of global public goods. Presented at Swiss Political Science Conference, Basel, January 28-29.

Barakat, S., Rzeszut, K., \& Martin, N. (2012). What is the track record of multi-donor trust funds in improving aid effectiveness. DFID and EPPI-Centre, University of London.

Barnett, M., \& Coleman, L. (2005). Designing police: Interpol and the study of change in international organizations. International Studies Quarterly, 49(4), 593-620.

Barnett, M. N., \& Finnemore, M. (1999). The politics, power, and pathologies of international organizations. International Organization, 53(4), 699-732.

Barnett, M., \& Finnemore, M. (2004). Rules for the world: International organizations in global politics. Ithaca (NY): Cornell University Press.

Bauer, M. W., \& Ege, J. (2016). Bureaucratic autonomy of international organizations' secretariats. Journal of European Public Policy, 23(7), 1019-1037.

Bayer, P., Marcoux, C., \& Urpelainen, J. (2014). Choosing international organizations: When do states and the World Bank collaborate on environmental projects?. Review of International Organizations, 9(4), 413-440.

Bayram, B., \& Graham, E. (2016). Financing Global Governance: Explaining Donor Funding Patterns at International Organizations. Drexel University, mimeo.

BNPP (2013). FY13 Annual Report on Portfolio Performance. Bank-Netherlands Partnership Program, Concessional Finance and Partnerships Group. Washington D.C.: World Bank.

Brechin, S. R., \& Ness, G. D. (2013). Looking back at the gap: international organizations as organizations twenty-five years later. Journal of International Organizations Studies, 4, 14-39.

Breton, A., \& Wintrobe, R. (1982). Logic of Bureaucratic Conduct: An Economic Analysis of Competition, Exchange, and Efficiency in Private and Public Organization. New York: Cambridge University Press. 
Brown, R. L. (2010). Measuring delegation. Review of International Organizations, 5(2), $141-175$.

Browne, S., \& Weiss, T. G. (2014). The future UN development agenda: contrasting visions, contrasting operations. Third World Quarterly, 35(7), 1326-1340.

Bryner, G. C. (1987). Bureaucratic discretion. New York: Pergamon Press.

Caughey, D., Chatfield, S., \& Cohon, A. (2009). Defining, mapping, and measuring bureaucratic autonomy. Presented at Midwest Political Science Conference, April 25.

Conceição-Heldt, E. (2013). Do agents "run amok"? A comparison of agency slack in the EU and US trade policy in the Doha Round. Journal of Comparative Policy Analysis: Research and Practice, 15(1), 21-36.

Cortell, A. P., \& Peterson, S. (2006). Dutiful agents, rogue actors, or both? Staffing, voting rules, and slack in the WHO and WTO. In: Hawkins, D. et al. (Eds.).

Delegation and Agency in International Organizations. Cambridge, UK: Cambridge University Press.

Danaher, K. (Ed.). (1994). 50 years is enough: the case against the World Bank and the International Monetary Fund. New York: South End Press.

Devex (2015). Jim Kim reorganizes 'global practices,' appoints senior staff. Available at http://www.devex.com/news/jim-kim-reorganizes-global-practices-appoints-seniorstaff-86091 (Accessed August 18, 2016).

Dijkstra, H. (2015). Shadow bureaucracies and the unilateral control of international secretariats: Insights from UN peacekeeping. Review of International Organizations, 10(1), 23-41.

Downs, A. (1967). Inside bureaucracy. Santa Monica (CA): Rand Corporation.

Dunleavy, P. (1991). Bureaucracy, democracy and public choice. Hemel Hemsted: Harvester Wheatsheaf.

Eichenauer, V., \& Hug, S. (2015). The politics of special purpose trust funds. Paper presented at the PEIO Conference, February 12-14, Berlin.

Eichenauer, V., \& Reinsberg, B. (2017). What determines earmarked funding to international development organizations? Evidence from the new multi-bi aid dataset. Review of International Organizations 12(2).

Elsig, M. (2011). Principal-agent theory and the World Trade Organization: Complex 
agency and 'missing delegation'. European Journal of International Relations, 17(3), 495-517.

Fiorina, M. P., \& Noll, R. G. (1979). Majority rule models and legislative elections. The Journal of Politics, 41(04), 1081-1104.

Frey, B. S. (1984). The public choice view of international political economy. International Organization, 38(1), 199-223.

Gehring, T. (2009). Die Autonomie Internationaler Organisationen. Lehren aus der systemtheoretischen Organisationstheorie. In: Dingwerth, K. et al. (Eds.). Die Organisierte Welt. Internationale Beziehungen und Organisationsforschung, 60-95.

Goetz, K. H., \& Patz, R. (2016). Pressured budgets and the European Commission: towards a more centralized EU budget administration?. Journal of European Public Policy, 23(7), 1038-1056.

Graham, E. R. (2013). International organizations as collective agents: Fragmentation and the limits of principal control at the World Health Organization. European Journal of International Relations, 1, 1-25.

Graham, E. R. (2015). Money and multilateralism: how funding rules constitute IO governance. International Theory, 7(1), 162-194.

Graham, E. R. (2016). The institutional design of funding rules at international organizations: Explaining the transformation in financing the United Nations. European Journal of International Relations, doi: 10.1177/1354066116648755.

Haas, E. B. (1964). Beyond the Nation-state: Functionalism and International Organization. Stanford (CA): Stanford University Press.

Hawkins, D. G., \& Jacoby, W. (2006). How agents matter. In: Hawkins, D. et al. (Eds.). Delegation and Agency in International Organizations, Cambridge (MA): Cambridge University Press, 199-227.

Hawkins, D. G., Lake, D. A., Nielson, D. L., \& Tierney, M. J. (Eds.). (2006). Delegation and agency in international organizations. Cambridge (MA): Cambridge University Press.

Heimans, J. (2004). Multiactor global funds: New tools to address urgent global problems, WIDER Research Paper No. 2004/47. World Institute for Development Economics Research, Helsinki.

Honig, D. (2015). Navigating by Judgment: Organizational Structure, Autonomy, and 
Country Context in Delivering Foreign Aid. Presented at the Political Economy of International Organizations conference, Berlin, Feburary 12-14.

IEG (2011). Trust fund support for development: an evaluation of the World Bank's trust fund portfolio, Independent Evaluation Group. Washington D.C.: World Bank.

IEG (2014). Learning and Results in World Bank Operations: How the Bank Learns Evaluation 1. Independent Evaluation Group. Washington D.C.: World Bank.

Jolly, R. (2014). UNICEF (United Nations Children's Fund): Global Governance that Works. London: Routledge.

Johnson, T. (2014). Organizational progeny: Why governments are losing control over the proliferating structures of global governance. Oxford: Oxford University Press.

Johnson, T., \& Urpelainen, J. (2014). International Bureaucrats and the Formation of Intergovernmental Organizations: Institutional Design Discretion Sweetens the Pot. International Organization, 68(1), 177-209.

Kaul, I., Grunberg, I., \& Stern, M. A. (1999). Global public goods: concepts, policies and strategies. In: UNDP (Ed.). Global public goods: International cooperation in the 21st century, Oxford: Oxford University Press, 450-507.

Koremenos, B., Lipson, C., \& Snidal, D. (2001). The rational design of international institutions. International Organization, 55(4), 761-799.

Lake, D. A., \& McCubbins, M. D. (2006). The logic of delegation to international organizations. In: Delegation and agency in international organizations, 341-368.

Linn, J. F. (1998). Unfunded Mandates: A Difficult Juggling Act. World Bank Staff Association Newsletter, Washington D.C.: World Bank.

Lyne, M. M., Nielson, D. L., \& Tierney, M. J. (2006). Who delegates? Alternative models of principals in development aid. In: Delegation and agency in international organizations, 41-76.

Mahn, T. (2012). The Financing of Development Cooperation at the United Nations: Why more means less. DIE Briefing Paper 8/2012, German Development Institute, Bonn.

Michaelowa, A., \& Michaelowa, K. (2011). Climate business for poverty reduction? The role of the World Bank. Review of International Organizations, 6(3-4), 259-286. 
Michaelowa, K., Reinsberg, B., \& Schneider, C. (2016). Multi-bi Aid in European Development Assistance: The Role of Capacity Constraints and Member State Politics. In: Bodenstein, T. et al. (Eds.). EU Development Policy: Collective Action in Times of Global Transformation and Domestic Crisis (Development Policy Review, forthcoming).

Nielson, D. L., \& Tierney, M. J. (2003). Delegation to international organizations: Agency theory and World Bank environmental reform. International Organization, 57(2), 241-276.

Niskanen, W. A. (1973). Bureaucracy - servant or master?: Lessons from America. London: Institute of Economic Affairs.

OECD (2011). 2011 Multilateral Aid Report. Organization for Economic Co-operation and Development. DCD/DAC(2011)21/FINAL. Paris.

OECD (2013). Creditor Reporting System. Organization for Economic Co-operation and Development. Available at http://stats.oecd.org (accessed September 2012 and July 2013). 
Economics of Foreign Aid. Northampton (MA): Edward Elgar.

Reinsberg, B., Michaelowa, K., \& Knack, S. (2016). Which Donors, Which Funds? The Choice of Multilateral Funds by Bilateral Donors at the World Bank. International Organization (forthcoming).

Romer, T., \& Rosenthal, H. (1978). Political resource allocation, controlled agendas, and the status quo. Public Choice, 33(4), 27-43.

Santos Silva, J., \& Tenreyro, S. (2011). Further simulation evidence on the performance of the Poisson pseudo-maximum likelihood estimator. Economics Letters, 112(2), $220-222$.

http://blogs.worldbank.org/voices (Accessed July 30, 2016).

Suchman, M. C. (1995). Managing legitimacy: Strategic and institutional approaches. Academy of Management Review, 20(3), 571-610.

Thibodeau, J. (1996). The World Bank's Procurement Myth. Washington D.C.: Cato Institute.

Trondal, J. (2012). On bureaucratic centre formation in government institutions: lessons from the European Commission. International Review of Administrative Sciences. $78(3), 425-446$.

Trondal, J. (2013). International bureaucracies: organizational structure and behavioural implications. In: Reinalda, B. (Ed.). Routledge handbook of international organization. London: Routledge.

UN (2000). Resolution adopted by the General Assembly 55/2. United Nations Millennium Declaration. Available at 
http://www.un.org/millennium/declaration/ares552e.htm (Accessed January 12, 2016)

UN (2012). Analysis of funding of operational activities for development of the United Nations system for the year 2010. Report of the Secretary General. UN Department of Economic and Social Affairs. New York.

UNDG (2015). UNDG Guidance on Establishing, Managing and Closing Multi-Donor Trust Funds. Available at https://undg.org/wp-content/uploads/2015/04/MDTFGuidance-Final-version-UNDG-approved-26.10.15.docx (Accessed August 18, 2016).

Vaubel, R. (1986). A public choice approach to international organization. Public Choice, 51(1), 39-57.

Vaubel, R. (2006). Principal-agent problems in international organizations. Review of International Organizations, 1(2), 125-138.

Vaubel, R., Dreher, A., \& Soylu, U. (2007). Staff growth in international organizations: A principal-agent problem? An empirical analysis. Public Choice, 133(3-4), 275-295.

Wapenhans, W. (1992). Effective Implementation: Key to Development Impact: Report of the World Bank's Portfolio Management Task Force. Washington D.C.: World Bank.

Weaver, C. (2007). The World's Bank and the bank's world. Global Governance, 13(4), 493-512.

Weaver, C. (2008). Hypocrisy trap: The World Bank and the poverty of reform. Princeton (NJ): Princeton University Press.

Wilson, J. Q. (1989). Bureaucracy: What government agencies do and why they do it. New York: Basic Books.

World Bank (2001). Assessment of the Strategic Compact. Available at http://wwwwds.worldbank.org/servlet/WDSContentServer/WDSP/IB/2003/09/04/000012009 20030904134425/Rendered/PDF/265180Scode0901of0Strategic0Compact.pdf (Accessed January 10, 2015).

World Bank (2003). FY 04 World Bank Budget. Corporate Finance and Risk Management. Washington D.C.: World Bank.

World Bank (2005a). 2004 Trust Fund Annual Report. Washington, D.C.: World Bank. Available at http://documents.worldbank.org/curated/en/2005/01/5678607/worldbank-group-2004-trust-funds-annual-report-year-ended-june-30-2004 (Accessed 
November 1, 2015).

World Bank (2005b). The World Bank's Budget: Trends and Recommendations for FY06. Strategy and Resource Management Vice Presidency. May 25. Washington D.C.: World Bank.

World Bank (2007a). The World Bank's Budget: Trends and Recommendations.

Concessional Finance and Partnerships Vice Presidency. May 16. Washington D.C.: World Bank.

World Bank (2007b). A Management Framework for World Bank-Administered Trust Funds. Concessional Finance and Partnerships Vice Presidency. September 14. Washington D.C.: World Bank.

World Bank (2012a). The Matrix System at Work: An Evaluation of the World Bank's Organizational Effectiveness. Available at http://dx.doi.org/10.1596/9780821397152 App-A (accessed August 4, 2016).

World Bank (2012b). Trust Fund Handbook: Digital Edition, revised version, Concessional Finance and Global Partnerships (version June 29, 2012).

World Bank (2013a). 2012 Trust Fund Annual Report. Concessional Finance and Partnerships Vice Presidency. Washington D.C.: World Bank.

World Bank (2013b). 2013 Trust Fund Annual Report. Concessional Finance and Partnerships Vice Presidency. Washington D.C.: World Bank.

World Bank (2013c). Identifying politically contested topics at the Bank Expert survey conducted at the World Bank, https://docs.google.com/forms/d/1JIEmuYFs TOPo2mI65jkhQn6icPc1pCty6NiQ0Tk5gX4/viewform (accessed February 12, 2014).

World Bank (2013d). BP 14.40, Annex A - Trust Funds Minimum Size. Available at http://go.worldbank.org/ZICVWBFOH0 (Accessed February 12, 2014).

World Bank (2013e). Trust Fund Reforms: Progress to Date and Future Directions. Confidential document presented to the Board of Executive Directors, Concessional Finance and Global Partnerships, June 12. Washington D.C.: World Bank.

World Bank (2013f). Trust fund databases: Contributions. Concessional Finance and Partnerships Vice Presidency. Washington D.C.: World Bank.

World Bank (2013g). Trust fund databases: Disbursements. Concessional Finance and Partnerships Vice Presidency. Washington D.C.: World Bank.

World Bank (2013h). Trust fund databases: Main trustees. Concessional Finance and 
Partnerships Vice Presidency. Washington D.C.: World Bank.

World Bank (2013i). World Bank project database.

http://go.worldbank.org/IAHNQIVK30 (Accessed December 1, 2013).

World Bank (2014). FY 14 World Bank Budget. Corporate Finance and Risk Management. Washington D.C.: World Bank.

World Bank (2015). World Bank Budget FY 15. Available at http://documents.worldbank.org/curated/en/911341468155118328/World-Bankbudget-FY15 (Accessed August 10, 2016).

World Bank (2016). The World Bank Group A to Z. Washington D.C.: World Bank. 


\section{Web Appendix A}

This web appendix complements the paper by providing a formalization of the bargaining relationship between a host unit and an implementing unit and a statistical test of its empirical implications. The results are consistent with the interview-based findings: The factors that were found to underlie the rise of pass-on funds based on interviews are similar to the ones testable through statistical analysis.

The web appendix entails two parts. The first is a formal model capturing the bargaining situation between a host unit and an implementing unit. This model generates predictions that are empirically testable. The second part thus assesses these predictions using a dyadic dataset of pass-on fund decisions at the World Bank from the past decade.

\section{A1 A pass-on funds bargaining model}

Consider the following model to study the interaction between a network unit (hosting the fund) and a regional unit (using the fund). While the model is fitted to the particular context of intra-organizational bargaining at the World Bank, it is generally applicable to a wider range of settings, characterized by two units within an organization whose interests diverge.

Each unit receives ordinary appropriations as a function of long-term predetermined quotas. For example, when the Board of Governors holds its replenishment meetings for the International Development Association (IDA), donor countries define the overall resource envelope and the distribution of IDA funds to the regional units. Arguably, these allocations are exogenous from the perspective of a regional unit. Moreover, each unit can raise its own extra-budgetary money through trust funds. In these so-called own funds, each unit raises money to support its ongoing activities. While own funds can be exactly tailored to client needs, they likely involve administrative costs and human resources related to the maintenance of donor relations. For the sake of simplicity, assume that own funds are predetermined.

The central tenet of this game hence refers to the cross-unit interaction on passon funds. Each individual grant from a pass-on funds consists of a monetary transfer $(x)$ and an issue platform $(\theta)$. I let $x$ be exogenous in this model, which simplifies the analysis. However, the substantive focus of a pass-on fund is endogenous and lies on a single-dimensional continuum $(\theta \in[0, \infty[)$, whose two extremes are a countryspecific platform $(\theta=0)$ and a sector-specific platform $(\theta \rightarrow \infty)$. Both units have 
different preferences regarding the pass-on fund platform. The network unit prefers a "sector-centered platform," which would involve a strong thematic focus that emphasizes the global dimension of a problem without considering country-specific needs. Conversely, the regional unit prefers a "country-centered platform," which would require the fund to consider the specific context of the country being assisted and hence prevent the network unit from learning lessons at the global level.

For the regional unit, both the platform and the resource envelope are payoffrelevant. The regional unit prefers a country-centered platform, but it may compensate a lack of country-specific alignment of the fund with a higher resource envelope from the pass-on fund. Hence, there is a fundamental tradeoff for the regional unit from using pass-on funds. These funds often do not exactly match country needs but they provide additional resources that translate into new business.

The basic structure of interaction between the units and their payoff schedules follow the agenda-setting model by Romer and Rosenthal (1978), albeit with simplifying adaptations of the actor space and the parameter space. The timing of the interaction involves three steps. In the first step, nature determines the parameter $\rho \geq 0$, the substantive focus of an activity that the regional unit will undertake when no pass-on fund comes into being. For example, $\rho$ may represent the platform achievable through own funds, which may depend on external factors such as the availability of like-minded donors at the country level. In the second step, the network unit $(N)$ decides whether $(e=1)$ or not $(e=0)$ to enter fundraising for a pass-on fund, and if it does so, it proposes a "fund platform" $(\theta \in[0, \infty[)$ to the regional unit. If $N$ does not enter, it will be able to work an additional amount of time on its own work program that it does not spend on fundraising, which would yield the additional payoff of $b$. If $N$ enters, it has to pay a fundraising $\operatorname{cost} c(\theta)$, regardless of whether or not unit $R$ accepts. Note that the platform together with other parameters, for example the availability of bilateral donor funding for specific sectors, determine the fundraising costs. In the last step, the regional unit $(R)$ either accepts $(r=1)$ or rejects $(r=0)$ the proposal, leading to either "no fund" or a pass-on fund. This decision will be informed by the relative attractiveness of the proposal $(\theta)$ given the outside option $(\rho)$. If $N$ had not proposed anything in the first place, the payoff can arbitrarily be set to zero. If $R$ accepts, it faces the disutility in terms of platform misalignment but gains an additional amount of grant resources that becomes more valuable the more $R$ has embraced sector-specific platforms. If $R$ rejects, it simply considers the alignment of the outside option with its own platform preference. 
Summarizing the above discussion, I hence postulate the following payoff functions for the two units:

$$
\begin{aligned}
& u_{N}(e, \theta \mid r)=\left\{\begin{array}{l}
b, \text { if } e=0 \\
\theta-c(\theta), \text { if } e=1
\end{array}\right. \\
& u_{R}(r \mid \theta, e=1)=\left\{\begin{array}{l}
-\rho^{2}, \text { if } r=0 \\
\left(x^{2}+2 x \rho\right)-(\theta-\rho)^{2}, \quad \text { if } r=1
\end{array}\right.
\end{aligned}
$$

Note that the utility function of the regional unit incorporates the tradeoff between additional resources through the pass-on fund and the misalignment with country priorities by design (though the functional form of the term $x^{2}+2 x \rho$ has been chosen purely for computational simplification later on).

The game can be solved using backward induction as both players decide sequentially under complete information. The last player to move is unit $R$, deciding whether or not to accept a given proposal. $R$ accepts under the following condition (then simplified in the last line):

$$
\begin{array}{r}
u_{R}(r=1 \mid \theta, e=1) \geq u_{R}(r=0 \mid \theta, e=0) \\
\left(x^{2}+2 x \rho\right)-(\theta-\rho)^{2} \geq-\rho^{2} \\
-\left(x^{2}+2 x \rho\right)+\theta^{2}-2 \rho \theta \leq 0 \\
\theta \leq \rho+\sqrt{\rho^{2}+2 x \rho+x^{2}} \\
\theta \leq \rho+\sqrt{(\rho+x)^{2}} \\
0 \leq \theta \leq 2 \rho+x
\end{array}
$$

The solution of the participation constraint (condition 8) shows that issue alignment and grant funding are substitutes. If the fund provided very little funding $(x \rightarrow 0)$, the highest acceptable platform should not be bigger than twice the platform of the outside option. Conversely, for higher grant amounts, the highest acceptable platform linearly increases. In the following, denote $\theta_{R}$ the value that just satisfies condition 8 , hence $\theta_{R}=\{\theta \mid \theta=2 \rho+x\}$.

Anticipating this best response, $N$ optimally wishes to satisfy condition 8 , given that failure to do so leaves it with a lower payoff (note that $N$ must always pay fundraising costs if it enters the fundraising game). Therefore, $N$ calculates its best proposal that satisfies condition 8 and then compares the implied utility with the utility of its outside option, valued at $b$.

Suppose that $N$ has raised a pass-on fund, then its optimal platform would be 
the solution of the following maximization problem, subject to the constraint 8:

$$
\begin{array}{r}
\max _{\theta_{\mid e=1}} \theta-c(\theta) \\
\frac{\partial}{\partial \theta}=1-c^{\prime}(\theta)=!^{!} 0
\end{array}
$$

Without further functional form assumptions, the optimal result is implicit. Let $\theta_{N}$ denote the value of $\theta$ that just satisfies condition 10, hence $\theta_{N}=\left\{\theta \mid c^{\prime}(\theta)=\right.$ 1 . Since $N$ satisfies the participation constraint of $R$, it follows that $N$ chooses whichever platform - either $\theta_{N}$ or $\theta_{R}$ - is smaller,

$$
\theta_{\mid e=1}=\min \left\{\theta_{R}, \theta_{N}\right\}
$$

The last step in solving the model involves calculating the condition under which $N$ enters the fundraising stage. $N$ perfectly foresees which platform it must choose (condition 11) after the fundraising stage. For $N$ to be willing to raise a pass-on fund, the following condition must hold:

$$
\begin{array}{r}
u_{N}\left(e=1 \mid \theta_{\mid e=1}, r=1\right) \geq u_{N}(e=0) \\
\theta_{\mid e=1}-c\left(\theta_{\mid e=1}\right) \geq b
\end{array}
$$

Denote as $\theta_{b}$ the platform at which $N$ is just indifferent between entering fundraising and staying out, in which case $N$ raises a pass-on fund and proposes $\theta_{\mid e=1}$, hence $\theta_{b}=\{\theta \mid b=\theta-c(\theta)\}$.

Depending on parameters, two different subgame-perfect Nash equilibria exist.

No-fund equilibrium In the first case, $N$ finds its entry costs so high or its outside option so attractive that it stays out of the game, hence $e=0$ and $\theta=0$. The best response by $R$ is to reject, $r=0$. It is easy to see that no player can improve its own payoff given the best response of the other player.

Pass-on fund equilibrium In the second case, $N$ finds it beneficial to enter the fundraising stage. $N$ proposes a platform that $R$ will accept (technically, for an equilibrium with pass-on fund, both conditions 10 and 8 must be satisfied). The location of the proposal depends on parameters. If $\theta_{N}>2 \rho+x$, then $N$ must choose $\theta^{*}=2 \rho+x$ in order to respect the participation constraint. This 
indeed is a subgame-perfect Nash equilibrium as no actor has an incentive to change its best response given the strategy of the other player (for $N$, any lower platform leaves room for a further utility improvement, but any larger platform triggers rejection; $R$ does not have an incentive to deviate given the proposal within the necessary bounds away from $2 \rho+x)$. Alternatively, imagine $2 \rho+x \geq \theta_{N}$. The equilibrium obtains at $\theta_{N}$, and $R$ accepts because it is better than its own outside option. $N$ also does not have an incentive to deviate.

In summary, the game has two equilibria, one in which the host does not raise a fund and the user rejects the proposal, and one in which the host raises a fund and proposes a fund platform that the user can just accept. Equilibrium choice hinges on exogenous parameters. For example, if the host is unable to make any proposal that would satisfy the participation constraint of the user, then the host does not make any proposal. In that case, $N$ would be left with its own work program, supported through Bank budget and Bank-executed trust funds, whereas $R$ would be left with IBRD/IDA projects and own funds.

Comparative statics can be derived once I parametrize the cost function and the outside option. For instance, assume that fundraising costs are $c(\theta, h, d)$ and hence are a function that depends on the chosen platform $(\theta)$, trust fund regulation $(h)$, and donor availability $(d)$. Similarly, I assume that the relative value of the outside option can be captured in a function $\rho(g, t)$ which depends on the grant composition of these resources $(g)$, and the level of trust in the host unit $(t)$. This leads to a number of testable hypotheses presented in the following.

First and foremost, anecdotal evidence suggests that budget constraints are the most important reason as to why individual units pursue trust funds. For almost all trust funds, the host unit deducts a small fee for secretariat services from the donor contributions and thereby increases its own administrative budget. ${ }^{27}$ This implies that network units may perceive pass-on funds as a useful strategy to fill gaps in their own budget especially when the latter has depleted. The first hypothesis hence reads as follows:

Bank budget hypothesis An decrease in $b$ makes entry into fundraising more

\footnotetext{
${ }^{27}$ For a few cases, the World Bank agreed with the donors to waive the fee, notably in the case of debt relief trust funds. These funds are administratively easy to handle and there was agreement that the resources should benefit the recipient to the fullest extent possible (World Bank 2012b: $17)$.
} 
likely; hence, the equilibrium probability of pass-on funding increases, everything else equal.

In recent years, the World Bank leadership has tightened its control on trust funds, enacting a number of reforms to discourage further fundraising. A watershed reform was the so-called "Trust Fund Management Framework," approved by the Executive Board in FY 2007. Before the reform, for example, network units could have a parallel dialogue in a recipient country besides the country unit. After the reform, such an activity would need approval by the respective country director. ${ }^{28}$. Bank management also increased the minimum threshold for donor contributions to create a new fund. ${ }^{29}$ Besides raising the minimum threshold from USD 200,000 to USD 1 million, the reform also introduced a start-up fee of USD 35,000 and augmented the fees for some types of trust funds (World Bank 2007b: v). In essence, the trust fund reforms most likely increased the costs for fundraisers inside the Bank.

Host regulation hypothesis Regulation $h$ is a cost parameter (note from above that $c$ depends on multiple factors, i.e., $c(\theta, h, d, \ldots)$ such that $\frac{\partial}{\partial h}>0$. An increase in $h$ negatively affects entry into fundraising and hence the probability of pass-on funding, everything else equal.

The potential resource base from which network units can solicit new funds should directly impact the number of pass-on funds. Since the Millennium Declaration (UN 2000), awareness among donors for development challenges with a global scope has been rising. Prior to that, the concept of "Global Public Goods" as championed in an influential paper commissioned by the United Nations Development Program paved the way for a renewed attention on global problems (Kaul, Grunberg, and Stern 1999). Many bilateral donors reoriented their aid budgets toward global activities. At the same time, individual donors also pushed their thematic priorities in the newly established working groups of the Donor Assistance Committee (DAC) at the Organization for Economic Cooperation and Development (OECD). Established at an increasing rate since the early 2000s, these informal groups discuss global development issues and thereby help raise awareness for specific themes and disseminate best practices among the donors. An increasing availability of global funding and an increasing awareness of global development themes hence should ease the constraints on the network units to establish pass-on funds.

\footnotetext{
28 Interview with Trust Fund Coordinator (August 2, 2013)

${ }^{29}$ Interview with Director (August 9, 2013)
} 
Donor availability hypothesis Donor abundance $d$ is an inverse cost parameter (in the above notation, $\frac{\partial c}{\partial d}<0$ ); hence, if it is easier to obtain funding from external donors, the probability of pass-on funding increases, everything else equal.

The above hypotheses include factors that affect the cost-benefit calculus of a network unit in its decision whether or not to engage in fundraising. Similarly, the regional units face exogenous conditions that affect the way in which they resolve the postulated tradeoff between misalignment between the fund platform and their own needs and the additional resource envelope made available by the pass-on fund.

First and foremost, the outside options of a regional unit affect its willingness to accept a proposal. In particular, I am concerned with the non-monetary component of these outside options, and I consider two exogenous conditions as being important in that regard.

Since trust funds essentially provide grant funding to recipient countries, they may be particularly valuable for regional units whose client countries are ineligible for grant funding. In particular, beneficiary countries with medium levels of per-capita income are restricted to borrow at non-concessional rates while being excluded from concessional resources. In cases in which the country does not want to borrow, it also does not benefit from the technical expertise of World Bank staff that usually comes along with a loan. A trust fund may provide the country with precious expertise through a donor-supported grant. This is attractive not only for the recipient country but also for the respective unit because the grant may promote future lending. ${ }^{30}$ My next hypothesis hence reads as follows:

Grant funding hypothesis An increase in the share of IBRD-only countries $g$ in the portfolio of unit $R$ represents a weaker outside option, corresponding to a higher value of $\rho(g, t)$. Everything else equal, this leads to a higher probability of pass-on funding.

In addition, pass-on funding opportunities are often about the relationships of individual people inside a multilateral bureaucracy. Therefore, the level of trust between host unit and implementing unit should have a positive relationship on the collaboration through pass-on funds.

\footnotetext{
${ }^{30}$ There are numerous cases in which a trust fund supporting technical assistance has led to a subsequent Bank loan. For a long time, this was the stated aim of the Policy and Human Resource Development (PHRD) program supported by a Japanese trust fund (PHRD 2012).
} 
Mutual trust hypothesis Higher trust $t$ implies that both units are characterized by preexisting similarities in terms of substantive focus. This should reduce the cost of fundraising (for example, since $N$ has lower uncertainty regarding its funds not remaining idle), and $R$ would be more willing to accept a proposal from this unit than any other unit. Any such interpretation is consistent with a positive effect of mutual trust on the probability of pass-on funding.

In principle, there also is a hypothesis on the (exogenous) amount of grant funding that $R$ can obtain from $N$ through the pass-on fund. Theoretically, a higher amount of funding should positively relate to a higher probability of pass-on funding. I refrain from testing this relationship though, because a higher number of pass-on funds should also explain the pass-on fund amount - hence, there is simultaneity. Inclusion of the variable "Pass-on fund amount" in a variety of lagged specifications does not alter the coefficients of interest, with the exception of "Global funding," with which it is positively correlated and hence global funding turns insignificant.

\section{A2 Empirical analysis}

This section includes the empirical analysis, proceeding with a brief description of the data and the operationalization of the variables of interest to test the hypotheses. After having discussed estimation methods, I present the main results along with a set of robustness tests.

\section{A2.1 Data}

I use a dataset of all activities supported from pass-on funds from FY 2002-13 (World Bank 2013g). The unit of analysis is the dyad-year observation, where a dyad consists of a network unit serving as host of fund and a regional unit as fund user. As discussed earlier, the reverse case of the regional unit being a host and the network unit being a user is irrelevant and hence all dyads with that division of labor are excluded. The dependent variable is the number of pass-on funds hosted by a given network unit and implemented by a given regional unit in a fiscal year. While funding volumes could also be considered, I prefer the number of funds in order to account for the many different purposes of pass-on funds that have different average funding requirements. The number of funds essentially reflects the degree of success of inter-organizational bargaining. 
I turn to the operationalization of the hypotheses. First, I use the lagged amount of Bank budget of a given network unit to test the first hypothesis. I logarithmize this variable to remove skewness and use a one-year lag in order to not lose too many observations as Bank budget figures are publicly available only since 2001. I construct the Bank budget variable from the budget reports of the World Bank (e.g., World Bank 2014).

Second, to capture pass-on funding regulation, I calculate a time-varying measure of regulation that captures the extent to which a network unit would be affected by the Trust Fund Management Framework (TFMF). I compute an index of regulatory pressure facing the host unit in three important areas of trust fund regulation. ${ }^{31}$ As only one such area, consider for example the setup fee. If a unit previously raised funds without charging donors a setup fee as it was introduced with the TFMF reform, the unit would score high in this area. The basis for computation represents all the trust funds created by the network unit in the past three years. High values on the regulation index reflect high regulatory pressure and painful adjustments in the post-TFMF period. ${ }^{32}$ Note that I cannot simply include a binary indicator for the years after the TFMF reform because its effect cannot be identified in the presence of year effects. Dropping the year effects is not an option because I want to account for global shocks affecting the outcome of interest.

Third, as discussed in the hypothesis section, there are two measures to capture the availability of thematic funding from bilateral donors. The first one considers the logged amount of bilateral aid available for global purposes, drawn from the Creditor Reporting System (OECD 2013). This measure requires the assumption that the bilateral aid allocations of donor countries are positively related to their willingness to support pass-on funds at the World Bank. This is realistic because trust funds are covered by the bilateral aid budget in most donor countries and almost all pass-on funds operate on a global scale. The second measure considers the number of donors that chair an OECD/DAC working group. As these groups discuss global development issues such as poverty reduction, gender equality, and climate change, it can be plausibly assumed that increased attention for such topics should relate to a higher amount of financial resources potentially available to passon funds. Both measures cannot be used simultaneously as they vary over the same

\footnotetext{
${ }^{31}$ For more information on the reform process, see World Bank (2013c-e).

32 The precise calculation of the index involved averaging over the shares of three types of trust funds that would be affected by the TFMF reform. The shares were mean-variance standardized (see the Appendix for a complete description).
} 
dimension. More fine-grained measures are plagued by specific problems though. For example, an alternative could be the relative weight of specific sectors in the bilateral aid allocation. ${ }^{33}$ This measure would be problematic due to its assumption that a reshuffling in the bilateral aid budget toward a specific sector does benefit the network unit at the World Bank. The measure also escapes straightforward operationalization because the OECD/DAC donors and the World Bank have different sector definitions and hence the sector mappings between them are prone to measurement error. Another alternative measure of sector-specific salience, notably the number of donors that chair an OECD/DAC working group in the sector(s) featuring in the work program of the network unit, suffers at least from the problem of correctly matching OECD/DAC sectors into World Bank sectors (see the Appendix for variable definitions). Results that use these latter two measures should be interpreted with a grain of salt.

Fourth, a key concept on the demand side for pass-on funds reflects the outside options of the regional unit. The program budget of a regional unit captures these outside options. The program budget consists of IBRD/IDA projects and own funds raised by the regional unit itself. To mitigate the impact of outliers and to capture the idea of economies of scale, I take the logarithm of the IBRD/IDA project size for all projects of a unit approved by Executive Board in the past three years (World Bank 2013i). Moreover, I include the logged amount of own funds (own calculations, based on World Bank 2013g). ${ }^{34}$

Fifth, the grant-funding hypothesis states that regional units with a higher share of countries that are ineligible for concessional funding through conventional sources are more likely to rely on pass-on funds. I therefore include the percentage of the project volume provided as IBRD loans (rather than IDA commitments) implemented by the unit in the past three years (World Bank 2013i).

Sixth, I require a measure of mutual trust between the two units. Each IBRD/IDA project is assigned a Sector Board, which is in charge of aligning sector programs with country-specific needs. Therefore, a higher percentage of projects through a Sector Board indicates prior interaction between the two units and hence an opportunity to build trust and mutual understanding about joint priorities. I assume that

\footnotetext{
33 Other papers have taken a similar approach, for example by comparing sector allocations of international organizations and their member states (Schneider and Tobin 2016) and by calculating a coefficient of variation in sector shares among donors (Reinsberg, Michaelowa, and Knack 2016).

34 A more precise measure of program resources from own funds only involves the co-financing trust funds of the regional unit. This measure may be used for robustness tests.
} 
fruitful inter-unit collaboration in the past should correlate with fruitful collaboration in the future. Therefore, I use the percentage of IBRD/IDA projects of the regional unit over the past three years passing the Sector Boards administered by a given network unit (World Bank 2013i) as a proxy of inter-unit trust.

\section{A2.2 Methods}

While theoretically a host unit may decide not to raise pass-on funds at all and an implementing unit may decide not to accept any proposed funds at all, these instances are rare in the dataset. Only $15 \%$ of all dyad-year observations involve no pass-on funds. As I have no reason to expect these observations to be driven by a different mechanism than the observations with a positive number of pass-on funds, I conduct a unified panel analysis with the number of pass-on funds for each possible host-user dyad as the dependent variable. As the dependent variable involves count data, I estimate a Poisson model, using Pseudo-Poisson maximum likelihood with fixed effects on both dyads and years (Santos Silva and Tenreyro 2011). I also allow for arbitrary correlations in the errors by computing a robust variance-covariance matrix clustered for dyads (Simcoe 2008). ${ }^{35}$

The econometric model reads as

$$
E\left(y_{i j t} \mid X_{i j t}, \alpha_{i j}, \phi_{t}\right)=\exp \left(X_{i j t} \beta+\alpha_{i j}+\phi_{t}\right)
$$

whereby $\beta$ contains the parameter estimates, $\alpha_{i j}$ represents the fixed effect on dyad $(i, j)$, and $\phi_{t}$ captures global shocks to the number of pass-on funds. The inclusion of two-way fixed effects mitigates potential bias due to omitted variables.

As regards further control variables, I include the logged amount of program funding from alternative sources of the regional unit. It is likely that a large amount of IBRD/IDA resources may affect both Bank budgets and the number of passon funds. To avoid spurious correlation, this variable should be included. In a robustness check, I also include a regional unit's own funds for the same reason. ${ }^{36}$

\footnotetext{
35 While clustering for host units would be a conceptually attractive option, it is not an empirically feasible one due to the low number of host units and the reliance on asymptotics of the cluster-robust standard errors.

${ }^{36}$ Further control variables could be included, which would not alter the coefficients of interest though.
} 


\section{A3 Results}

Table A1 presents the main results. Column 1 only includes the predictors relating to host-unit hypotheses. All predictors have the predicted sign and are statistically significant. Column 2 includes the predictors relating to the users of pass-on funds. Except for the IBRD/IDA program funding, whose coefficient cannot be distinguished from zero, all indicators turn out as expected. Column 3 combines both sets of covariates, which does not change their respective signs as compared to when they were included separately.

Consider the predictions based on column 3 for a few cases. For example, when all variables are held at their respective means, the average number of pass-on funds being created amounts to 6.0. If then the host-unit Bank budget declines by $33 \%$, the unit raises about 6.4 funds, an increase by about 7\%. Alternatively, if host-unit regulation had increased by one standard deviation, the number of pass-on funds would have reduced to 5.7. Conversely, an increase in aid for global purposes from donor countries by $10 \%$ would lead to an increase in the number of pass-on funds to 6.3 funds. If the implementing unit had a higher percentage of IBRD-only countries by one standard deviation, the predicted number of pass-on funds would be 6.4 funds. Finally, an improvement in mutual trust as reflected in the history of joint IBRD/IDA projects by one standard deviation relates to additional pass-on funding of about 0.1 funds. Goodness-of-fit measures represent the pseudo- $R^{2}$, calculated as the relative improvement in the likelihood from a baseline model with only the two-way fixed effects.

Overall, these results are consistent with the hypotheses shown in the previous section. To probe the robustness of these results, the next section conducts a sensitivity analysis based on different variable definitions.

Table A2 presents some robustness checks. Column 1 replaces Log(Global aid) with the number of chairs in the OECD/DAC working groups. It turns out that this measure proxies funding for global purposes equally well as the money amount itself, given its strongly significant coefficient. Column 2 replaces Log(Global aid) by its underlying change in absolute dollar amounts from year to year. The analysis indicates that pass-on funding seems to increase after an increase in global-purpose aid. The next two columns again use $\log ($ Global aid) but add measures of salience for the specific sector(s) in which the network unit has its stakes. 
Table A1: Determinants of pass-on funds: Main results

$(2)$

(3)

\begin{tabular}{|c|c|c|c|}
\hline Log(Bank budget) & $\begin{array}{l}-0.809^{* * *} \\
(0.170)\end{array}$ & & $\begin{array}{l}-0.832^{* * *} \\
(0.163)\end{array}$ \\
\hline Host regulation & $\begin{array}{l}-0.528^{* * *} \\
(0.181)\end{array}$ & & $\begin{array}{l}-0.563^{* * *} \\
(0.128)\end{array}$ \\
\hline $\log ($ Global aid $)$ & $\begin{array}{l}1.088^{* * *} \\
(0.241)\end{array}$ & & $\begin{array}{l}0.671^{* * *} \\
(0.237)\end{array}$ \\
\hline Percentage of IBRD countries & & $\begin{array}{l}0.010^{*} \\
(0.006)\end{array}$ & $\begin{array}{l}0.010^{* *} \\
(0.004)\end{array}$ \\
\hline Mutual trust & & $\begin{array}{l}0.013^{* *} \\
(0.006)\end{array}$ & $\begin{array}{l}0.017^{* * *} \\
(0.005)\end{array}$ \\
\hline Log(IBRD/IDA budget) & & $\begin{array}{l}0.173 \\
(0.108)\end{array}$ & $\begin{array}{l}0.154^{*} \\
(0.083)\end{array}$ \\
\hline $\mathrm{N}$ & 498 & 576 & 498 \\
\hline McFadden- $R^{2}$ & 0.13 & 0.03 & 0.16 \\
\hline
\end{tabular}

Notes: Two-way fixed effects for host-user dyads and individual years included. Dyad-clustered standard errors shown in parentheses. 
Table A2: Determinnats of pass-on funds: Robustness checks
(1)
(2)
(3)
(4)
(5)
(6)

Log(Bank budget)

\begin{tabular}{llllll}
$-0.832^{* * *}$ & $-0.832^{* * *}$ & $-0.781^{* * *}$ & $-0.726^{* * *}$ & $-0.665^{* * *}$ & $-1.238^{* * *}$ \\
$(0.163)$ & $(0.163)$ & $(0.153)$ & $(0.137)$ & $(0.135)$ & $(0.309)$ \\
& & & & & $0.017^{*}$ \\
& & & & & $(0.010)$ \\
$-0.563^{* * *}$ & $-0.563^{* * *}$ & $-0.592^{* * *}$ & $-0.643^{* * *}$ & $-0.743^{* * *}$ & $-0.553^{* * *}$ \\
$(0.128)$ & $(0.128)$ & $(0.153)$ & $(0.153)$ & $(0.141)$ & $(0.130)$ \\
$0.130^{* * *}$ & $0.030^{* * *}$ & $0.614^{* *}$ & $0.473^{*}$ & $0.102^{* *}$ & $0.640^{* * *}$ \\
$(0.043)$ & $(0.008)$ & $(0.254)$ & $(0.260)$ & $(0.050)$ & $(0.238)$ \\
& & 0.008 & $0.051^{* * *}$ & & \\
$0.010^{* *}$ & $0.010^{* *}$ & $(0.010)$ & $(0.012)$ & & \\
$(0.004)$ & $(0.004)$ & $(0.004)$ & $(0.004)$ & $(0.004)$ & $(0.004)$ \\
$0.017^{* * *}$ & $0.017^{* * *}$ & $0.017^{* * *}$ & $0.016^{* * *}$ & $0.017^{* * *}$ & $0.016^{* * *}$ \\
$(0.005)$ & $(0.005)$ & $(0.005)$ & $(0.005)$ & $(0.006)$ & $(0.005)$ \\
$0.154^{*}$ & $0.154^{*}$ & $0.151^{*}$ & $0.151^{*}$ & $0.207^{*}$ & $0.153^{*}$ \\
$(0.083)$ & $(0.083)$ & $(0.080)$ & $(0.078)$ & $(0.113)$ & $(0.083)$ \\
& & & & 0.007 & \\
& & & & $(0.004)$ & \\
& & & & $-0.015^{* * *}$ & \\
& & & & $(0.005)$ & \\
\hline
\end{tabular}

Log(Total size of own funds)

(0.005)

$\begin{array}{lllllll}\mathrm{N} & 498 & 498 & 498 & 498 & 456 & 498 \\ \text { McFadden- } R^{2} & 0.16 & 0.16 & 0.16 & 0.18 & 0.25 & 0.16\end{array}$

p-values: *.1 $* * .05 \quad * * * .01$

Notes: Two-way fixed effects for host-user dyads and individual years included. Dyad-clustered standard errors shown in parentheses.

a) Different measures used for sensitivity checks, notably $\log ($ Global aid) (columns 3, 4, and 6), the change in global aid (column 2), the number of chairs in DAC working groups (column 1 and 5).

b) Different measures used for sensitivity checks, notably the average percentage of the sector(s) in bilateral aid featuring in a network unit's work program (column 3) and the number of chairs in DAC working groups relevant for the network unit's sector(s) (column 4). 
While there is no relationship between the average share of the sector(s) in the bilateral aid portfolios (column 4), there indeed is a positive effect of the number of donors that chair a DAC working group in the specific sector(s) being relevant to the network unit. ${ }^{37}$ Column 5 adds alternative sources of program budget for the regional unit, notably the dollar value of own funds as well as its overall number. It turns out that conditional on the number of own funds, their dollar value has a negative relationship with pass-on funds. This suggests that the bigger the projects that a regional unit can implement through its own funds, the less it needs to draw on pass-on funding. ${ }^{38}$

Finally, in column 6, the set of hosts is divided into units whose services feature prominently in IBRD/IDA projects and those that do not. This allows for a more narrow test of the key quote in the IEG report according to which especially the network units that were crowded out of the country programs should have most incentives to pursue trust funds. For this purpose, I include an interaction between the host-unit Bank budget and the importance of a unit in core-funded projects over the past three years. As expected, the Bank budget has a less negative relationship with pass-on funds for units with a prominent role in core projects.

Overall, these results are consistent with the hypotheses put forward in the previous section. First and foremost, budget constraints are an important driver of trust funds. Especially the decline in the Bank budget jeopardized the perceived security of the network units, which hence turned to trust funds as a supplementary source of income. However, the regional units do not rely on trust funds to prop up their program budget. In fact, the weakly positive association between their IBRD/IDA resources and the number of pass-on funds even suggests a complementarity between pass-on funds and IBRD/IDA projects in that these trust funds support related activities that are critical for the success of core-funded projects. Further support for this claim comes from the consistent positive effect of the importance of loans relative to grant funding: The more countries are eligible only for non-concessional loans, the higher the incentive for a regional unit to draw on a trust fund in order to bring in some grant funding. This stresses the importance of trust funds for the overall business of the World Bank.

Of course, the empirical results are merely correlational. However, I have sought

\footnotetext{
37 These results also hold if the global aid budget was replaced by the total number of DAC chairs (as used in column 1).

38 When including the latter two indicators separately, none of them is significant.
} 
to address potential concerns related to endogeneity by using fixed-effects estimation and lagging the predictors of interest. In addition, some qualitative evidence may help exclude the possibility of reverse causation. A key variable in my regressions represents the host-unit Bank budget, whose negative coefficient estimate could generally be interpreted in two ways.

One interpretation is that network units raised trust funds in response to a flat budget. There is abundant evidence in favor of this interpretation. One senior official in the Concessional Finance and Partnerships unit argued that "trust funds substitute for the Bank budget that we do not have," explaining that the Executive Board "has not increased the administrative budget since 2007." 39 An Executive Director admitted that "there is a link between the flat Bank budget and trust funds." 40

Another potential interpretation would be that network units incur costs from increased fundraising for pass-on funds that their administrative budgets must cover. In fact, the earlier budget reports of the Bank raise doubts about the financial sustainability of trust funds and their insufficient cost recovery. As early as in FY 2004, the Bank introduced a "standardized cost recovery policy for trust funds" (World Bank 2003: 23), and it further increased trust fund managing fees in the Trust Fund Management Framework (World Bank 2007b). It therefore seems highly unlikely that trust funds could have a tangible impact on the Bank budget.

\section{A4 Data description}

Pass-on funds (dependent variable) Count of the number of trust fund grants hosted by a network VPU and implemented by a regional VPU in a given year from FY 2002 to FY 2013. At the grant level, there is no ambiguity as to who are the relevant VPUs in the host-user dyad.

Source: World Bank (2013g)

$\log$ (Bank budget) Logarithm of the host unit's Bank budget, lagged by one year and deflated to 2012 constant million USD.

Source: World Bank (2014)

Host regulation Annual index of potential affectedness by trust fund regulation

\footnotetext{
39 Interview with Lead Operations Officer (August 26, 2013)

40 Interview with Adviser from a mid-sized donor (August 27, 2013)
} 
for the host unit, capturing the extent to which a network unit would be a affected by the Trust Fund Management Framework (TFMF); the index has three components, which reflect the respective percentages of trust funds raised by the network unit over the past three years that would be affected by the following regulatory items: (1) Percentage of trust funds that do not (yet) charge a setup fee; (2) percentage of trust funds that are likely to be (too) small, notably Bank-executed trust funds or single-donor trust funds; (3) percentage of trust funds whose fee structures are prone to cost underrecovery, notably co-financing funds, reduced-fee trust funds, and rate-cost recovery trust funds; these percentages are mean-variance standardized and aggregated into an index; higher values indicate higher potential affectedness by TFMF regulation

Source: World Bank (2013g)

$\log$ (Global aid) Logarithm of total funding from bilateral donors available for global purposes (recipientcode $=998$ )

Source: Creditor Reporting System (OECD/DAC 2013)

Change in global aid Absolute dollar amount change from year to year in the total volume of global aid (see the definition above)

Source: Creditor Reporting System (OECD 2013)

Number of DAC working groups Number of donor countries that chair an OECD/DAC working group in a given year Source: Reinsberg, Michaelowa, and Knack (2016)

Sector salience in bilateral aid Average percentage of a sector in the bilateral aid allocations of all OECD/DAC donor countries; Only those sectors are considered that are potentially relevant for the given network unit (sector matching available upon request)

Source: Creditor Reporting System (OECD 2013)

Sector salience in DAC working groups Number of donor countries that chair an OECD/DAC working group in the sector(s) potentially relevant for the given network unit in a given year

Source: Reinsberg, Michaelowa, and Knack (2016)

Percentage of IBRD countries Percentage of IBRD countries in the IBRD/IDA projects of the implementing unit over the past three years 
Source: World Bank (2013i)

Mutual trust Percentage of IBRD/IDA projects of the regional unit over the past three years passing the Sector Boards administered by a given network unit. Each IBRD/IDA project is assigned to only one Sector Board, which is in charge of aligning sector programs with country-specific needs.

Source: World Bank (2013i)

$\log ($ IBRD/IDA budget) Logarithm of the total size of IBRD/IDA projects (Lending project cost) activated by the regional unit over the past three years Source: World Bank (2013i)

Number of own funds Number of "own funds" raised by a regional unit in a given year; own funds are trust funds whose grants are used by the host unit itself

Source: World Bank (2013g)

$\log$ (Total size of own funds) Logarithm of total grant volume allocated by all "own funds" of a regional unit in a given year (see the above definition of own funds)

Source: World Bank (2013g)

Network involvement Percentage of IBRD/IDA projects across the World Bank over the past three years that went through the Sector Board associated to a given network unit

Source: World Bank (2013i) 
Table A3: Descriptive statistics for regressions on pass-on funds

\begin{tabular}{llllll} 
& Obs & Mean & Sd & Min & Max \\
\hline \hline & & & & & \\
Pass-on funds & 576 & 27.38 & 49.17 & 0.00 & 436.00 \\
Log(Bank budget) & 504 & 45.01 & 15.17 & 23.80 & 81.40 \\
Host regulation & 570 & -0.12 & 0.68 & -1.83 & 1.51 \\
Log(Global aid) & 576 & 23.58 & 0.40 & 23.00 & 24.11 \\
Change in global aid (1e+6) & 576 & 1.59 & 3.28 & -3.04 & 8.90 \\
Number of DAC working groups & 576 & 7.42 & 1.89 & 4.00 & 10.00 \\
Sector salience in bilateral aid & 576 & 21.28 & 12.89 & 3.22 & 43.04 \\
Number of DAC working groups & 576 & 3.11 & 2.47 & 0.00 & 9.00 \\
Percentage of IBRD countries & 576 & 68.20 & 33.30 & 0.24 & 98.63 \\
Mutual trust & 576 & 12.50 & 17.51 & 0.00 & 75.63 \\
Log(IBRD/IDA budget) & 576 & 24.45 & 0.63 & 22.82 & 25.62 \\
Number of own funds & 528 & 14.61 & 11.08 & 0.00 & 51.00 \\
Log(Total size of own funds) & 528 & 17.40 & 4.19 & 0.00 & 22.35 \\
Network involvement & 576 & 12.48 & 13.50 & 0.00 & 36.38 \\
\hline
\end{tabular}




\section{Web Appendix B}

\section{B1 Organizational reforms at the World Bank}

The World Bank restructured its internal functioning several times in history. Four phases relating to distinct organizational structures can be distinguished. In all phases, however, there has been a tension between regional VPUs and network VPUs. ${ }^{41}$

\section{Pre-1987}

The World Bank started out as a rather small organization. It managed a limited number of projects, and most of these projects were centrally managed. A lenient organizational structure hence was useful to strike a balance between functional differentiation and overall cost effectiveness. Management arrangements were hierarchical: Staff members and middle managers reported directly to a single line supervisor. Following the expansion of the Bank in the McNamara era, projects became increasingly regional. Therefore, the regional vice president increasingly had to play the role of a mediator between country-specific groups and sector groups.

1987

In 1987, former World Bank president Barber Conable further increased the functional differentiation of the two types of units to govern their relationship and to reduce the perceived lack of country orientation. The reform made CMUs responsible for the overall country strategy, while SMUs covered all technical aspects of project design for a relevant group of countries. This reform did not prove to be successful in all regards: "While [it] strengthened the country focus, technical staff worked primarily in country department silos and the technical quality of [...] project work deteriorated."

1997

As tensions between CMUs and SMUs continued and the country focus still had room for improvement, the World Bank launched a new reform dubbed "Strategic Compact" under the leadership of James Wolfensohn. Key aspects of the reform

\footnotetext{
41 This section is based on World Bank 2012a (pp.113-119). I also benefited from exchange with a few staff members at the World Bank.
} 
were the expedited decentralization of operations to the field to facilitate country dialogue, and the establishment of the network anchors (and Sector Boards) to link all SMUs across the Bank and hence make available global knowledge to country teams. In addition, the reform established dual reporting relationships and country budgets allocated by CMUs to different SMUs. It is this feature, "and not the creation of the networks [...], or decentralization," that makes the reform "qualitatively different from those that came earlier." After 1997, it was no longer possible for SMUs to deploy budget resources without approval by CMUs, which sought to reduce "supply-driven behavior" by SMUs. Laying budget authority in the hands of CMUs should align Bank operations closer to country demand.

Though not anticipated, the reform proved to be critical to the revival of World Bank operations in the realm of the Millennium Development Goals - adopted by the United Nations General Assembly in autumn 2000. The newly created network anchors served the growing demand for sector-specific global development expertise. Hence, in addition to their internal dissemination role, they were the outside face of the Bank on issues relating to their sectors. Consequently, the World Bank became a privileged partner on global public goods and cross-country challenges, although it was thought to be passive in response to external demands and lacked clear internal guidance.

\section{4}

Under the leadership of Jim Kim, the World Bank adopted an organizational reform that became effective on July 1, 2014. Maintaining the double matrix, the reform reorganized the relationship between former regions and former networks (called "Global Practices" to emphasize the potential for cross-fertilization among sector units in different regions). The network anchors were abolished and replaced by heads of global practices. The regional vice presidents were essentially relegated (as indicated by the dashed line running to the heads of Global Practices in the figure below): Primary accountability of SMU staff — relevant for salary increases and job promotions - is now to the Global Practice heads and not the regional Vice Presidents. In addition, the reform established "Cross-Cutting Solution Areas" whose function is to mainstream key development themes into Bank projects. The reform did not affect the operational matrix that supports the country operations and which consists of CMUs and SMUs. This is easily seen by comparing the former sectors with the new global practices (see Table B1) and by juxtaposing the before- 
Figure B1: World Bank organizational structure before and after the 2014 reform
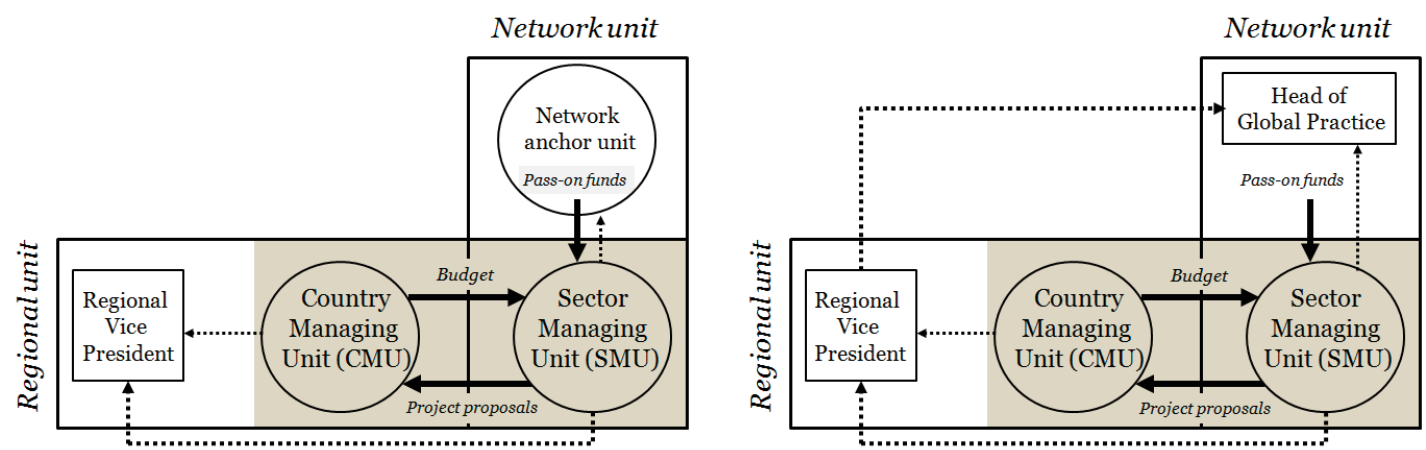

after organizational snapshots (Figure B1).

The organizational reform did not touch the regional matrix that governs the country-related operations of the Bank. In particular, there continues to be a dual line of accountability for sector teams working in specific countries. Additional informal staff interviews (conducted in 2016) confirm the impression that the reform did not have any significant consequences on operational teams (i.e., budget accountability and ability to charge time to projects have not changed). The fact that operational procedures changed little is also reflected in the continuity of the budget. The new budget (as reported on from FY 2015 onward) appears to be incommensurate with the old budget (as reported until FY 2014). Under the old structure, regional units and network anchors have separate budget lines in the program budget. The new structure does not feature individual line items for network VPUs or regional VPUs, but a country envelope - including all project-related work, knowledge services, and convening services - and a global envelope, which encompasses all activities without a specific client country (see World Bank 2015: 15). It is striking that this way of reporting carries forward the old accounting, albeit at a higher level of aggregation that limits empirical analysis for years after FY 2014. In fact, what now appears as global envelope essentially is the sum of program expenses of the former network anchors. The country envelope is the sum of the former regional VPUs. Even the allocation process is the same: The budget is notionally allocated to the regional VPUs, which then agree on a work program with the Global Practices (World Bank 2015: 15).

Ironically, for the donors, it might have become harder to identify the right sector counterparts in some Global Practices. This is because some Global Practices do not have recognizable anchor units. 
Table B1: Old sectors versus new global practices

$\begin{array}{ll}\text { Old structure (until FY 2014) } & \text { New structure (since FY 2015) } \\ & \\ \text { Sustainable Development Network } & \text { Global Practices } \\ \text { Agriculture, Fishing, and Forestry } & \text { Agriculture } \\ \text { Energy and Mining } & \text { Energy and Extractives } \\ \text { Transportation } & \text { Environment and Natural Resources } \\ \text { Information and Communications } & \text { Transport and ICT } \\ \text { Water, Sanitation, and Flood Protection } & \text { Water } \\ \text { Industry and Trade } & \text { Social, Urban, Rural, and Resilience } \\ & \\ \text { Human Development Network } & \\ \text { Education } & \text { Education } \\ \text { Health and other Social Services } & \text { Health, Nutrition, and Population } \\ \text { Social Protection } & \text { Social Protection and Labor } \\ \text { Labor Markets and Jobs } & \\ & \\ \text { Other networks } & \\ \text { Public Administration, Law, and Justice } & \text { Macroeconomic and Fiscal Management } \\ \text { Poverty } & \text { Poverty } \\ \text { Finance } & \text { Finance and Markets } \\ & \text { Governance }\end{array}$

Notes: There are three sets of Global Practices (as grouped in the table), each reporting to their own director (devex 2015). In addition to the Global Practices, there are four "Cross-cutting solution areas," including Climate Change; Fragility, Conflict, and Violence; Gender; Jobs; and Public-Private Partnerships.

Sources: Own illustration based on World Bank (2012a); World Bank (2016); devex (2015) 


\section{B2 Historical developments of own funds}

Since the beginning of trust funds, own funds have been the typical arrangement between an individual donor and its multilateral implementing agency. In the 1980s, many donors established consultant trust funds that financed staff secondments from national development agencies to the World Bank. In the 1990s, despite further evolution of trust fund purposes, both types of units relied on trust fund to support their respective activities. Regional units increased their efforts to solicit grantfunding opportunities for recipient countries, leading to an increase in the number of country-specific trust funds (Figure B2). The main beneficiaries of trust funds initiated during that period were Vietnam, Bangladesh, West Bank and Gaza, Pakistan, Indonesia, and Bosnia and Herzegovina (World Bank 2013h). In 1998, the Netherlands started the Bank-Netherlands Partnership Program (BNPP) to support pilot studies in a number of high-salience sectors, for example fragile states, gender equality, and reproductive health (BNPP 2013: 2). All these initiatives led to trust funds in support of specific sectors and hence involved the network units as main beneficiaries of the funds. Despite the different purposes of trust funds in regional units and network units, the trust funds created until FY 2000 had in common that they were raised and implemented by the same unit. They can thus be called "own funds." 
Figure B2: The evolution of own funds at the World Bank

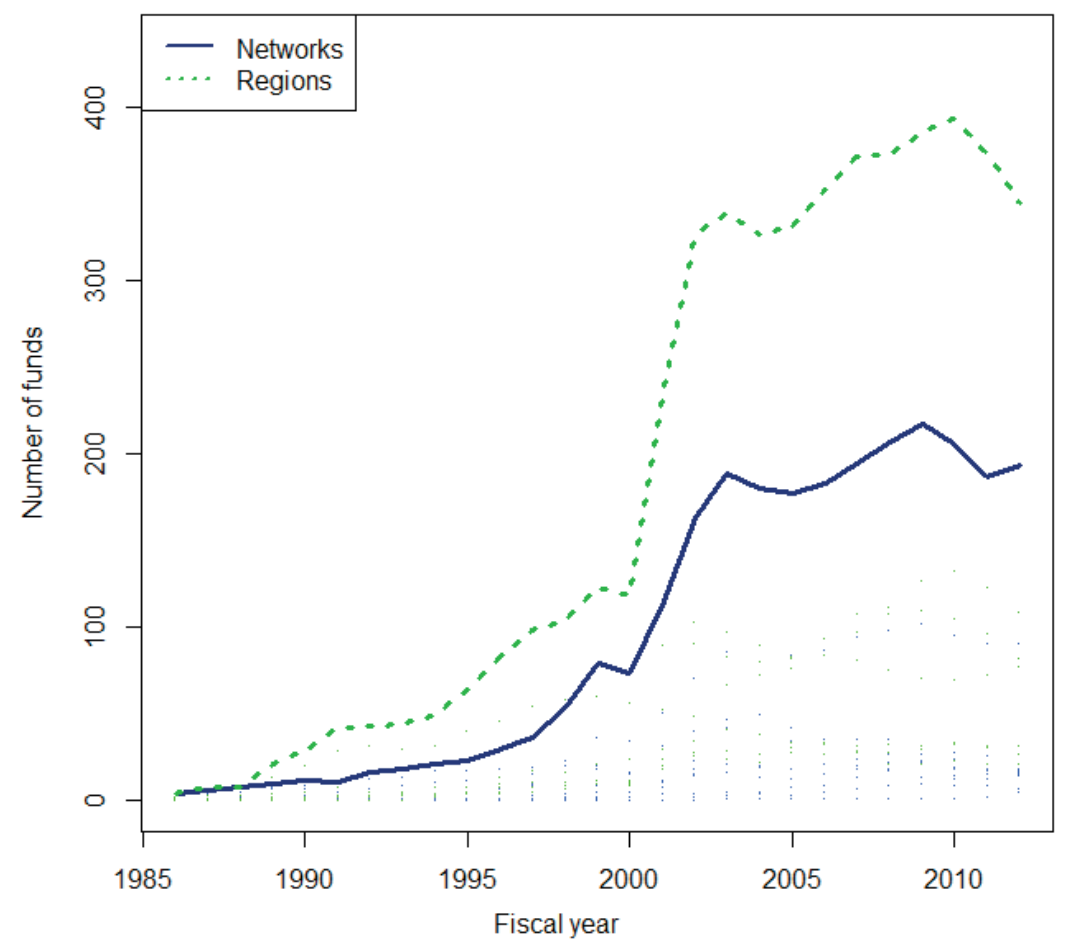

Notes: Thick lines show the total number of own funds being active in a fiscal year net of terminated funds by unit type. Individual dots of the corresponding color show the unit-specific data. Trust funds of the International Finance Corporation (IFC) are excluded.

Source: World Bank (2013h) 


\section{B3 Use patterns of pass-on funds (FY 2002-13)}

Another way of looking at the phenomenon of pass-on funds involves an analysis of "which units host funds" and "which units implement projects supported by funds." In general, each individual unit can be involved in trust funds in only three distinct ways. Either the unit hosts the trust fund and allocates the fund to its own work program (labeled "Host and user" in the figure), or the unit hosts a trust fund passing on its resources for implementation to another department (labeled "Host but not user"), or the unit uses a fund that it does not host itself (labeled "User but not host").

Using the World Bank trust fund databases, I detect considerable variation in these three possible roles in the analysis of inter-unit trust fund grants from 2002 to 2013. The largest difference in host-user patterns holds between regional units and network units. Figure B3 shows that regional units primarily are receivers of grants from trust funds established elsewhere in the Bank (yellow bars). In contrast, regional units almost never raise trust funds intended for implementation by other World Bank units (red bars). A moderate share of trust funds comes from own fundraising (blue bars). In contrast, network units to a large extent serve as hosts of trust funds that allocate trust fund grants to other departments. The largest units delegate more than half of their funds to other units, some units have an even higher share of delegated funds (red bars). Conditional on delegation, network units provide funding almost exclusively to regional units. In contrast, it is clearly the exception that network units take funding from elsewhere (yellow bars). Finally, there is significant heterogeneity among network units in the use of own funds (blue bars). These patterns suggest a simple conclusion: Network units primarily host trust funds, whereas regional units implement them. Each unit also may decide how much trust fund resources to raise through its own funds. 
Figure B3: Host-user relations between World Bank units

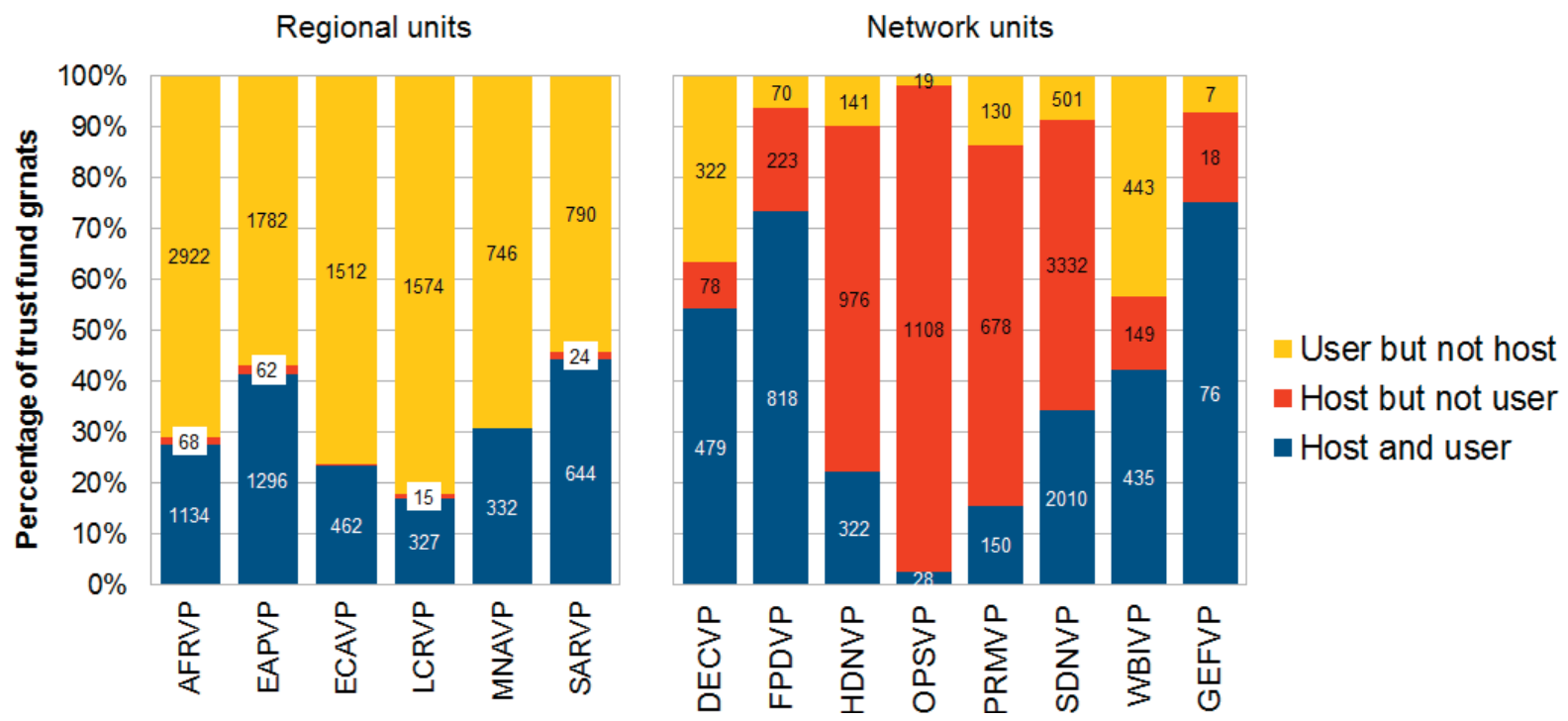

Notes: Left panel shows the six regional units and their distribution of fund types at the level of individual grants allocated between individual units. Right panel shows the corresponding figures for the network units. Numbers on the bars show the total number of grants in a given category provided between FY 2002-13. Regional unit vice presidencies are Africa (AFRVP), East Asia and Pacific (EAPVP), Europe and Central Asia (ECAVP), Latin America and the Caribbean (LCRVP), Middle East and North Africa (MNAVP), and South Asia (SARVP). Network unit vice presidencies are Development Economics (DECVP), Finance and Private Sector Development (FPDVP), Human Development Network (HDNVP), Operations and Country Services (OPSVP), Poverty Reduction and Economic Management (PRMVP), Sustainable Development Network (SDNVP), World Bank Institute (WBIVP), and Global Environment Facility (GEFVP).

Source: World Bank (2013g) 